\title{
\#USGS
}

science for a changing world

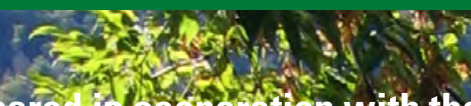

Prepareuldooptation with the

New Vol fato Dopartiment of Environimental Conservation

S.

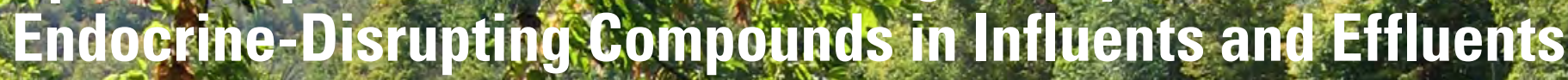
of Selected Wastewate 1 reathinent Plans and Rereiving

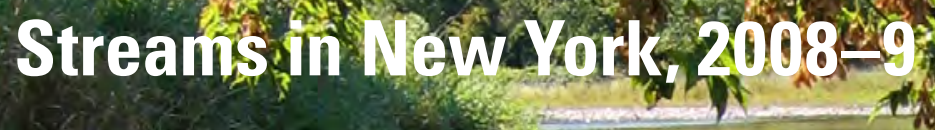

25 
Cover. West Branch of Delaware River (front cover) near Walton, N.Y., and wastewater-treatment plant outfall near Tannersville, N.Y. (back cover). 


\section{Spatiotemporal Variations in Estrogenicity, Hormones, and Endocrine-Disrupting Compounds in Influents and Effluents of Selected Wastewater-Treatment Plants and Receiving Streams in New York, 2008-9}

By Barry P. Baldigo, Patrick J. Phillips, Anne G. Ernst' James L. Gray, and Jocelyn D.C. Hemming

Prepared in cooperation with the

New York State Department of Environmental Conservation

Scientific Investigatiaons Report 2014-5015 


\title{
U.S. Department of the Interior SALLY JEWELL, Secretary
}

\section{U.S. Geological Survey \\ Suzette M. Kimball, Acting Director}

\author{
U.S. Geological Survey, Reston, Virginia: 2014
}

For more information on the USGS - the Federal source for science about the Earth, its natural and living resources, natural hazards, and the environment, visit http://www.usgs.gov or call 1-888-ASK-USGS.

For an overview of USGS information products, including maps, imagery, and publications, visit http://www.usgs.gov/pubprod

To order this and other USGS information products, visit http://store.usgs.gov

Any use of trade, firm, or product names is for descriptive purposes only and does not imply endorsement by the U.S. Government.

Although this information product, for the most part, is in the public domain, it also may contain copyrighted materials as noted in the text. Permission to reproduce copyrighted items must be secured from the copyright owner.

Suggested citation:

Baldigo, B.P., Phillips, P.J., Ernst, A.G., Gray, J.L., and Hemming, J.D.C., 2014, Spatiotemporal variations in estrogenicity, hormones, and endocrine-disrupting compounds in influents and effluents of selected wastewatertreatment plants and receiving streams in New York, 2008-09: U.S. Geological Survey Scientific Investigations Report 2014-5015, 32 p., http://dx.doi.org/10.3133/sir20145015.

ISSN 2328-0328 (online) 


\section{Contents}

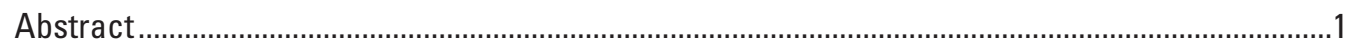

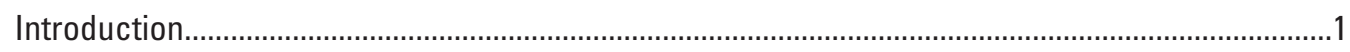

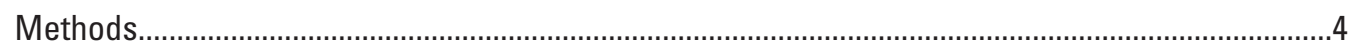

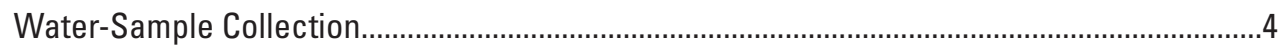

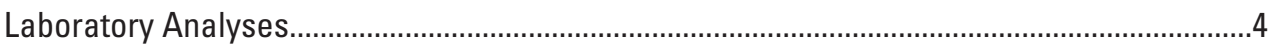

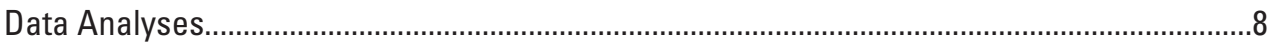

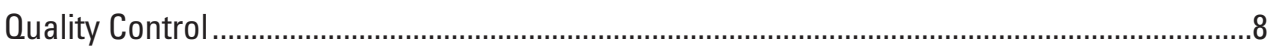

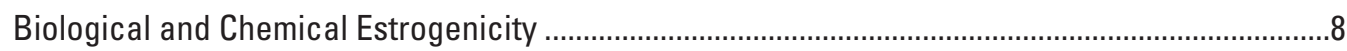

Constituent Concentrations .....................................................................................................20

Spatiotemporal Variations in Estrogen, Other Hormones, and Endocrine-Disrupting

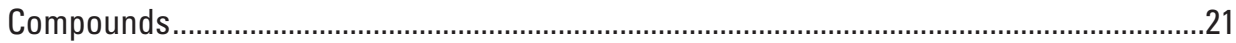

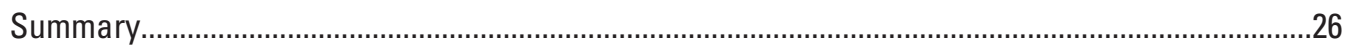

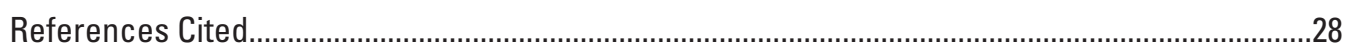

Appendix 1. Concentrations of wastewater compounds in unfiltered water from sites sampled as part of the estrogenicity study, 2008-9......................................................32

Appendix 2. Concentrations of hormones in unfiltered water from sites sampled as part

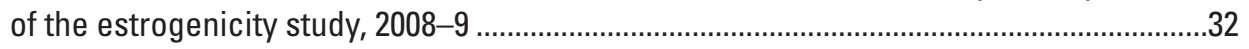

\section{Figures}

1. Maps showing the locations of 33 wastewater-treatment plants and selected surface-water sites sampled in New York, 2008-9 ........................................................

2. Graph showing biological estrogenicity measured in all effluent samples collected at 33 wastewater-treatment plants in New York, 2008-9................................................12

3. Graph showing biological estrogenicity in effluent samples collected at seven wastewater-treatment plants in New York during seasonal surveys, 2008-9................13

4. Graph showing chemical estrogenicity calculated from all effluent samples collected from 33 wastewater-treatment plants, 2008-9 …...............................................20

5. Diagram showing measured biological estrogenicity in relation to estimated chemical estrogenicity for all effluent and influent samples collected at 33 wastewater-treatment plants in New York, 2008-9 ......................................................21

6. Box plots of $A$, biological and $B$, chemical estrogenicity of treated wastewater effluents from five different treatment processes ........................................................22

\section{Tables}

1. Description, treatment type, drainage area, estimated stream discharge (annual average), permitted effluent discharge, approximate dilution, and sampling schedule for 33 wastewater-treatment plants and receiving streams in New York, sampled during 2008-9.

2. Hormones and non-hormone endocrine-disrupting compounds with low and high estradiol-equivalent weights used in calculating chemical estrogenicity......

3. Biological and chemical estrogenicity of water samples collected, by season and treatment efficacy, from 33 wastewater-treatment plants in New York, during 2008-9...9 
4. Concentrations of common endocrine-disrupting compounds, hormones, bisphenol $A$, and estimated estrogenicity for samples collected from wastewatertreatment plant effluents and influents, and receiving streams, in New York, 2008-9...14

5. Concentrations of total suspended solids in samples of wastewater-treatment-plant effluents and receiving streams, New York, 2008-9

\section{Conversion Factors and Datum}

\begin{tabular}{ccc}
\hline Multiply & By & To obtain \\
\hline & Flow rate & \\
\hline cubic foot per second $\left(\mathrm{ft}^{3} / \mathrm{s}\right)$ & 0.02832 & cubic meter per second $\left(\mathrm{m}^{3} / \mathrm{s}\right)$ \\
\hline
\end{tabular}

Vertical coordinate information is referenced to the North American Vertical Datum of 1988 (NAVD 88).

Horizontal coordinate information is referenced to the North American Datum of 1983 (NAD 83).

Concentrations of chemical constituents in water are given either in milligrams per liter (mg/L), nanograms per liter (ng/L), or micrograms per liter $(\mu \mathrm{g} / \mathrm{L})$.

\section{Abbreviations}

$\begin{array}{ll}\text { AS } & \text { activated sludge } \\ \text { AL } & \text { aerated lagoon } \\ \text { EDC } & \text { endocrine-disrupting compound } \\ \text { HDPE } & \text { high-density polyethylene } \\ \text { NCC } & \text { non-contact cooling } \\ \text { NWQL } & \text { National Water Quality Laboratory } \\ \text { NYC } & \text { New York City } \\ \text { NYCDEP } & \text { New York City Department of Environmental Protection } \\ \text { NYSDEC } & \text { New York State Department of Environmental Conservation } \\ \text { NYSDOH } & \text { New York State Department of Health } \\ \text { OWC } & \text { organic wastewater compound } \\ \text { PPCP } & \text { pharmaceutical or personal care product } \\ \text { RBC } & \text { rotating biological contactor } \\ \text { SBR } & \text { sequential batch reactor } \\ \text { TSS } & \text { total suspended solids } \\ \text { TF } & \text { trickling filter } \\ \text { USEPA } & \text { U.S. Environmental Protection Agency } \\ \text { USGS } & \text { U.S. Geological Survey } \\ \text { WETL } & \text { wetland } \\ \text { WWTP } & \text { wastewater-treatment plant }\end{array}$




\title{
Spatiotemporal Variations in Estrogenicity, Hormones, and Endocrine-Disrupting Compounds in Influents and Effluents of Selected Wastewater-Treatment Plants and Receiving Streams in New York, 2008-9
}

\author{
By Barry P. Baldigo' ${ }^{1}$ Patrick J. Phillips ${ }^{1}$, Anne G. Ernst ${ }^{1}$, James L. Gray', and Jocelyn D.C. Hemming ${ }^{2}$
}

\begin{abstract}
Endocrine-disrupting compounds (EDCs) in wastewater effluents have been linked to changes in sex ratios, intersex (in males), behavioral modifications, and developmental abnormalities in aquatic organisms. Yet efforts to identify and regulate specific EDCs in complex mixtures are problematic because little is known about the estrogen activity (estrogenicity) levels of many common and emerging contaminants. The potential effects of EDCs on the water quality and health of biota in streams of the New York City water supply is especially worrisome because more than 150 wastewater-treatment plants (WWTPs) are permitted to discharge effluents into surface waters and groundwaters of watersheds that provide potable water to more than 9 million people. In 2008, the U.S. Geological Survey (USGS), the New York State Department of Environmental Conservation (NYSDEC), New York State Department of Health (NYSDOH), and New York City Department of Environmental Protection (NYCDEP) began a pilot study to increase the understanding of estrogenicity and EDCs in effluents and receiving streams mainly in southeastern New York. The primary goals of this study were to document and assess the spatial and temporal variability of estrogenicity levels; the effectiveness of various treatment-plant types to remove estrogenicity; the concentrations of hormones, EDCs, and pharmaceuticals, personal care products (PPCPs); and the relations between estrogenicity and concentrations of hormones, EDCs, and PPCPs. The levels of estrogenicity and selected hormones, non-hormone EDCs, and PPCPs were characterized in samples collected seasonally in effluents from 7 WWTPs, once or twice in effluents from 34 WWTPs, and once in influents to 6 WWTPs. Estrogenicity was quantified, as estradiol equivalents, using both the biological e-screen assay and a chemical model. Results generally show that

${ }^{1}$ US Geological Survey.

${ }^{2}$ Wisconsin State Laboratory of Hygiene.
\end{abstract}

(1) estrogenicity levels in effluents varied spatially and seasonally, (2) a wide range of known and unknown EDCs were present in both WWTP effluents and receiving streams, (3) some effluents may be important sources of estrogenicity in weakly diluted streams, (4) measured levels of biological estrogenicity were often higher than estimated levels of chemical estrogenicity, and (5) the type of treatment had a large effect on the removal efficacy, and consequently, the estrogenicity levels observed in treated effluents.

\section{Introduction}

Knowledge of the effects of pharmaceuticals, hormones, and other contaminants in effluents from wastewatertreatment plants (WWTPs) on the quality of waters and biota in receiving streams has greatly increased during the period 1978-2011 (Peltier, 1978; Mount, 1982; USEPA, 1983b; Carlson and others, 1984; Kidd and others, 2007; Phillips and others, 2010; Schultz and others, 2010; Wang and others, 2010a; Schultz and others, 2011; Zhang and others, 2011). Many effluents contain complex mixtures of chemicals used in private homes, industry, and agriculture, such as human and veterinary drugs, hormones, detergents, disinfectants, plasticizers, fire retardants, insecticides, fragrances, and antioxidants (Kolpin and others, 2004). Many studies have found that natural and synthetic hormones, as well as other common organic and inorganic compounds, in WWTP effluents can alter the endocrine systems of native fish and wildlife (Goodbred and others, 1997; Kolpin and others, 2002; Clara and others, 2005; Zhang and Zhou, 2005; Castiglioni and others, 2006; Gordon and others, 2006; Kidd and others, 2007; Wang and others, 2010a). Some endocrine-disrupting compounds (EDCs) may pass through WWTPs and discharge into receiving streams in their original form or only partly altered, and their estrogenic or androgenic potency can 
sometimes increase or decrease depending upon specific treatment processes (Kolpin and others, 2002).

EDCs are ubiquitous contaminants of wastewater effluents, and recent research has linked their presence in the environment in general to changes in sex ratios, intersex changes (in males), behavior modifications, and developmental abnormalities in freshwater and marine invertebrates, fish, birds, and reptiles (Tyler and others, 1996; Guillette, 2000; Jobling and others, 2002; Jobling and Tyler, 2003; McCarthy and others, 2003; Baldigo and others, 2006; Beek and others, 2006; Cheek, 2006; Rempel and others, 2006; Blazer and others, 2007; Ford and others, 2007; Kidd and others, 2007; Iwanowicz and others, 2009; Jobling and others, 2009; Park and others, 2009; Wang and others, 2010b). The full effects of human exposure to EDCs have not been determined; thus, the long-term effects of chronic exposure to low doses of EDCs remain undefined. However, several studies reporting reduced fertility and increased occurrence of hormone-dependent cancers have raised public awareness (Foster, 2001; James, 2001; Green Brody and others, 2006). Determining which compounds qualify as EDCs has proved difficult, however, because there is no consensus in the scientific community on how to identify an EDC and because many chemicals have limited, incomplete evidence of endocrine activity or have not been tested for potential endocrine activity (Kim and others, 2007). The list of 26 known or suspected non-hormone EDCs used in this study is by no means complete; other pharmaceuticals and personal care products (PPCPs) may be identified as EDCs with further research.

In New York State, almost 1,900 public, private, and commercial WWTPs are permitted to release their effluents into surface water and groundwater. More than 150 WWTPs are located within the two major watersheds that provide drinking water to approximately 9 million people located in and around New York City. In reservoirs, EDCs generally do not reach concentrations that might be harmful to human health (Cao and others, 2010); however, the presence of EDCs within streams in the New York City (NYC) East of Hudson Water Supply watershed and the West of Hudson Water Supply watershed could potentially affect the health of resident fish and wildlife. Although hormone data are not available for most WWTPs in New York State, a recent assessment of organic wastewater compounds at four WWTPs in both New York City (NYC) watersheds indicates that wastewaters can contain a wide range of pharmaceuticals (Phillips and others, 2005; Phillips and others, 2010), some of which may act as hormone mimics (Harris and others, 2001; Nichols and others, 2001; Petrovic and others, 2002; Gibson and others, 2005; Nagy and others, 2005; Oh and others, 2006). The extent to which streamwaters across New York may contain measurable concentrations of EDCs, and the threat that these EDCs pose to wild fish populations and to human consumers of fish and water, remain largely undocumented.

Fortunately, the effects of emerging contaminants on aquatic biota and ecosystems can now be evaluated more effectively than in the past because of recent advances in methods used to quantify estrogen levels, or estrogenicity, and very low concentrations of hormones and non-hormone EDCs in water. In vitro techniques to measure estradiol equivalents (E2 Eq) using e-screen methods of Drewes and others (2005) and Soto and others (1995) are very sensitive and can reliably quantify estrogenicity in environmental samples (Leusch and others, 2010). In addition, analytical methods developed by the U.S. Geological Survey (USGS) (Kolpin and others, 2002; Zaugg and others, 2002) can now be used to quantify very low concentrations of hormones and EDCs in effluents. These procedures provide the tools needed to accurately characterize effluent quality, variations in levels of EDCs, the estrogenic effects that effluents may have on biota, and the effects that various sources (to WWTPs) and treatment processes (within WWTPs) have on the transport and fate of emerging contaminants in receiving waters.

The task to quantify the spatial extent and severity of harmful levels of estrogenicity, hormones, EDCs, and PPCPs in WWTP effluents (and potential estrogenic effects on biota in streams) throughout the State, however, remains daunting. Consequently, the USGS, in cooperation with the New York State Department of Environmental Conservation (NYSDEC) and collaboration with New York State Department of Health (NYSDOH), and New York City Department of Environmental Protection (NYCDEP), conducted a pilot study during 2008 targeting seven WWTPs, mostly within the two New York City watersheds (fig. 1). The primary objective of the effort was to improve the ability to protect aquatic biota and sources of drinking water from adverse effects caused by known and unknown estrogenic compounds that are frequently discharged from WWTPs. To meet this objective, estrogenicity of effluents was quantified, and the factors that affect spatial and temporal differences in estrogenicity were assessed for selected effluents in both New York City watersheds and at three industrial sites located in central and northern New York. Related goals of the study were to characterize the

- spatial and temporal variability in estrogenicity levels in effluents and receiving streams at selected WWTPs,

- effectiveness of various treatment-plant types in reducing or removing estrogenicity,

- concentrations of hormones, EDCs, and PPCPs in effluents and streams, and

- relations between estrogenicity and concentrations of selected hormones, EDCs, and PPCPs.

The main purpose of this report is to summarize levels of estrogenicity, selected hormones, EDCs, and PPCPs in WWTP influents and effluents and in receiving streams. The efficacy of the treatments used by WWTPs to remove the compounds from wastewater is also discussed. Samples were collected seasonally or synoptically from 33 WWTPs and receiving streams during 2008-9. 


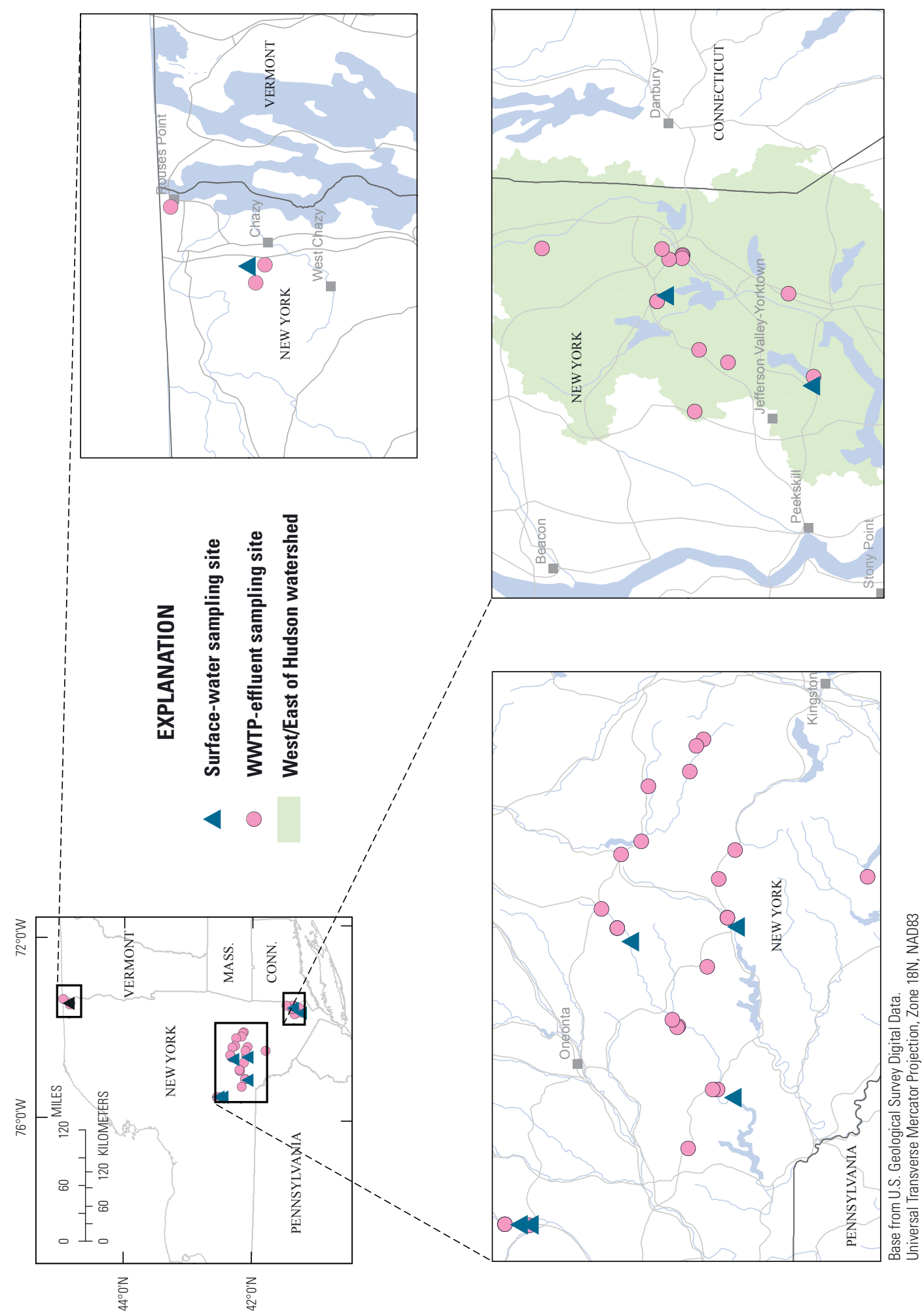

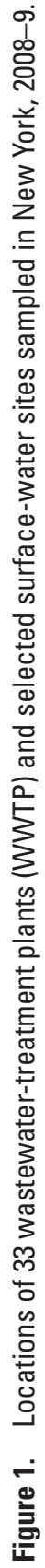


Spatiotemporal Variations in Estrogenicity, Hormones, and Endocrine-Disrupting Compounds, New York, 2008-9

\section{Methods}

Levels of estrogenicity and selected hormones, nonhormone EDCs, and other PPCPs were determined in samples collected (1) seasonally (4 times) from effluents from seven municipal and pharmaceutical WWTPs (fig. 1), (2) 1 or 2 times from the streams receiving these effluents, (3) 1 or 2 times from the effluents from 26 additional WWTPs in the NYC watersheds, and (4) 1 time from influents to six WWTPs. The various study sites (effluent, stream, and influent) were chosen to represent a range of different WWTP types: aerated lagoon (AL; 1 site), activated sludge (AS; 17 sites), rotating biological contactors (RBC; 9 sites), sequential batch reactor (SBR; 2 sites), a wetland (WETL; 1 site), and trickling filter (TF; 1 site) (table 1). Two of the WWTPs essentially had no secondary treatment because their effluents consisted only of non-contact cooling (NCC) water during the time of sample collection. Data from all of the sites and surveys were used to assess spatiotemporal variations and important inter-relations among target constituents.

\section{Water-Sample Collection}

Water samples were collected from a total of 33 WWTP effluents; abbreviated site codes and USGS station IDs are identified in table 1. Seasonal effluent samples were collected (July 2008, October 2008, January 2009, and April 2009) at four municipal WWTPs in the two NYC watersheds and three industrial (pharmaceutical) plants located outside of the New York City water-supply watersheds (fig. 1). Two industrial plants are in central New York, and one is in northeastern New York. Seasonal samples were collected from streamwaters receiving effluent within a few kilometers downstream from the outfall of the seven "seasonal" WWTPs during the July 2008 survey. Effluent samples were collected in October 2008 at 25 additional WWTPs in the NYC watersheds; one plant was sampled a second time in November 2008. Because estrogenicity was found to surpass background conditions at many sites, additional samples were collected in October 2009 at 12 WWTPs and in 8 receiving streams. At six of these WWTPs, 24-hour flow composite samples of influent and effluent were collected; at the remaining six, only effluent grab samples were collected.

All influent, effluent, and streamwater samples were collected in accordance with standard USGS methods (Shelton and Capel, 1994; USGS, 2006). Samples for PPCP and e-screen assays were collected in amber glass bottles. Samples for hormone analysis, total suspended solids, and toxicity were collected in high-density polyethylene (HDPE) bottles. In addition to 54 routine (grab) water samples, 7 field blanks (from five sites) and 7 replicate samples (from six sites) were collected for quality-control purposes.

All water samples were immediately placed on ice and returned to the USGS New York Water Science Center in Troy, N.Y., where, except for hormones (Schedule 4434), aliquots were shipped within 24 hours to four laboratories for respective analyses. The USGS National Water Quality Laboratory (NWQL) in Denver, Colorado, analyzed all EDCs, hormones, and PPCPs. The Wisconsin State Laboratory of Hygiene in Madison, Wisconsin, performed e-screen assays, and Adirondack Environmental Services in Albany, N.Y., analyzed total suspended solids (TSS). The hormone aliquots were stored frozen in 500-milliliter (mL) high-density polyethylene (HDPE) bottles at the USGS Laboratory in Troy, N.Y., until laboratory procedures for method SH4434 were approved by the NWQL during 2009 (Foreman and others, 2012).

The instantaneous or daily mean flow of WWTP effluents was obtained from the plant operator for the day that effluent samples were collected. The instantaneous discharge of the receiving streams was measured (when streamwater samples were collected) or estimated either directly from nearby USGS streamgages or indirectly from the drainage area for the sample site, and the drainage area and flow from distant USGS streamgages in the same subbasin or in nearby watersheds.

\section{Laboratory Analyses}

Water samples were analyzed for 69 wastewater indicator compounds typically found in domestic and industrial wastewater and nonpoint sources, and for four surrogate compounds at the USGS NWQL following USGS-approved methods for laboratory production schedule 4433 (Zaugg and others, 2002). These compounds included alkylphenol ethoxylate nonionic surfactants, food additives, fragrances, antioxidants, flame retardants, plasticizers, industrial solvents, disinfectants, fecal sterols, polycyclic aromatic hydrocarbons, and high-use domestic pesticides. Water samples were also analyzed for 28 hormones, surrogate hormones, and pharmaceuticals at the NWQL following USGS-approved methods for laboratory production schedule 4434 and laboratory code 8076 (Zaugg and others, 2002; Cahill and others, 2004; Foreman and others, 2012). These compounds included natural and synthetic androgens and estrogens, as well as several associated by-products.

Estrogenicity levels were determined by using (1) the biological (e-screen) assay, which quantifies estrogenicity as estradiol equivalents for extracts from water samples (Soto and others, 1995; Drewes and others, 2005) and (2) a chemical model that estimates probable estrogenicity using levels of hormones and non-hormone EDCs and their estrogen equivalency factors (Vajda and others, 2008) as described in the next paragraph. The e-screen assays quantify biological estrogenicity using a proliferation test with human estrogen receptor-positive MCF-7 breast cancer cells (Soto and others, 1995; Korner and others, 1999; Shappell, 2006). These breast cancer cells respond to compounds that bind to and activate the estrogen receptor by proliferating. Thus, the more estrogenic a water-sample extract is, the more cells that are exposed to such water extract will proliferate. The 
Table 1. Description, treatment type, drainage area, estimated stream discharge (annual average), permitted effluent discharge, approximate dilution, and sampling schedule for 33 wastewater-treatment plants and receiving streams in New York, sampled during 2008-9.

[AL, aerated lagoon; AS, activated sludge; NCC, non-contact cooling; WETL, wetland-landfill; RBC, rotating biological contactor; SBR, sequential batch reactor; TF, trickling filter, G, grab sample; C, 24-hour composite sample; ID, identifier; $\mathrm{mi}^{2}$, square miles; $\mathrm{ft}^{3} / \mathrm{s}$, cubic feet per second]

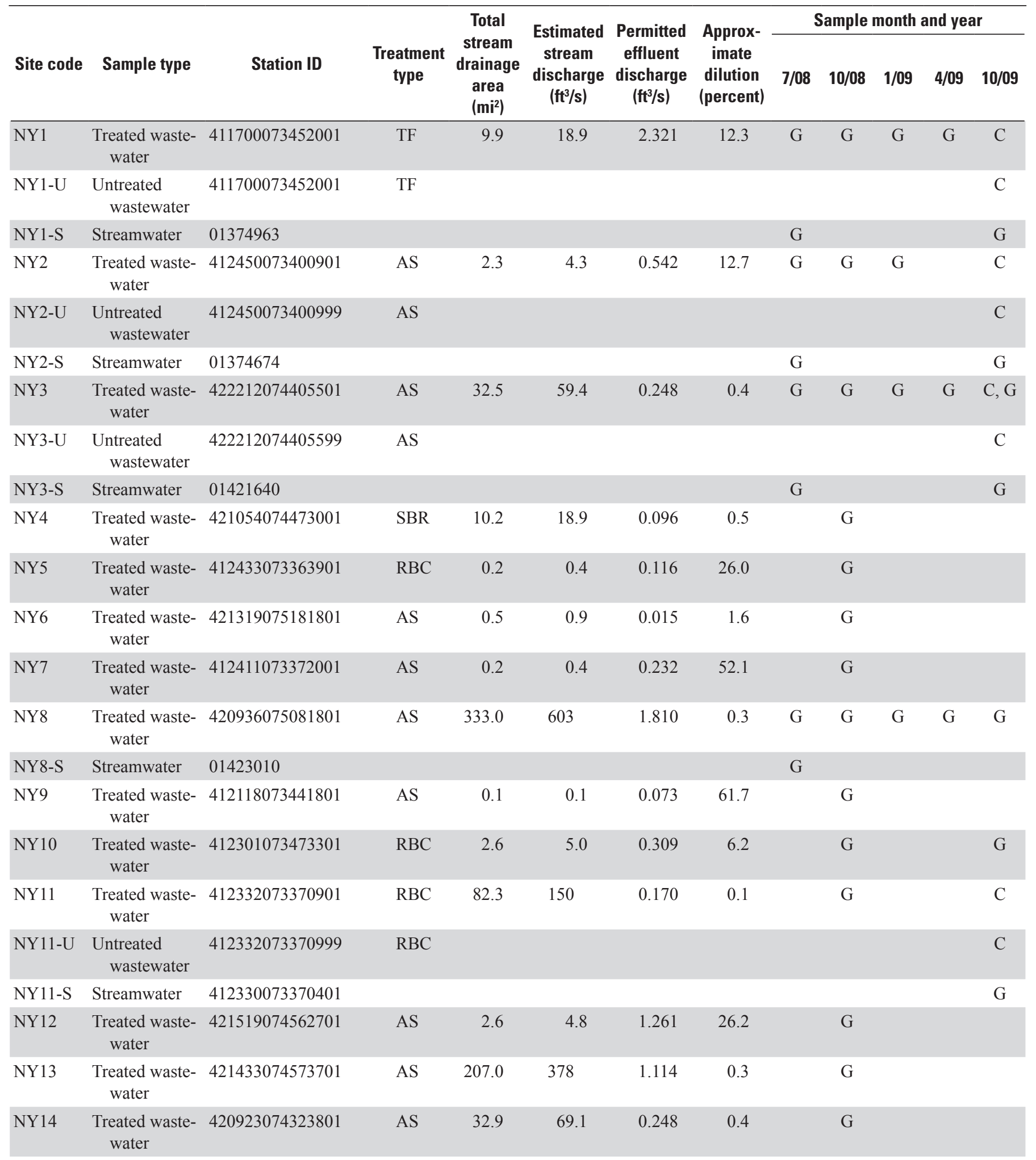


Table 1. Description, treatment type, drainage area, estimated stream discharge (annual average), permitted effluent discharge, approximate dilution, and sampling schedule for 33 wastewater-treatment plants and receiving streams in New York, sampled during 2008-9.-Continued

[AL, aerated lagoon; AS, activated sludge; NCC, non-contact cooling; WETL, wetland-landfill; RBC, rotating biological contactor; SBR, sequential batch reactor; TF, trickling filter, $\mathrm{G}$, grab sample; $\mathrm{C}$, 24-hour composite sample; ID, identifier; $\mathrm{mi}^{2}$, square miles; $\mathrm{ft}^{3} / \mathrm{s}$, cubic feet per second]

\begin{tabular}{|c|c|c|c|c|c|c|c|c|c|c|c|c|}
\hline \multirow[b]{2}{*}{ Site code } & \multirow{2}{*}{ Sample type } & \multirow[b]{2}{*}{ Station ID } & \multirow{2}{*}{$\begin{array}{l}\text { Treatment } \\
\text { type }\end{array}$} & \multirow{2}{*}{$\begin{array}{c}\text { Total } \\
\text { stream } \\
\text { drainage } \\
\text { area } \\
\left(\mathrm{mi}^{2}\right)\end{array}$} & \multirow{2}{*}{$\begin{array}{l}\text { Estimated } \\
\text { stream } \\
\text { discharge } \\
\left(\mathrm{ft}^{3} / \mathrm{s}\right)\end{array}$} & \multirow{2}{*}{$\begin{array}{l}\text { Permitted } \\
\text { effluent } \\
\text { discharge } \\
\left(\mathrm{ft}^{3} / \mathrm{s}\right)\end{array}$} & \multirow{2}{*}{$\begin{array}{l}\text { Approx- } \\
\text { imate } \\
\text { dilution } \\
\text { (percent) }\end{array}$} & \multicolumn{5}{|c|}{ Sample month and year } \\
\hline & & & & & & & & 7/08 & $10 / 08$ & $1 / 09$ & $4 / 09$ & $10 / 09$ \\
\hline NY15 & $\begin{array}{l}\text { Treated waste- } \\
\text { water }\end{array}$ & 413034073362801 & AS & 4.7 & 8.3 & 0.015 & 0.2 & & $\mathrm{G}$ & & & $\mathrm{G}$ \\
\hline NY17 & $\begin{array}{l}\text { Treated waste- } \\
\text { water }\end{array}$ & 415038074322601 & $\mathrm{RBC}$ & 21.2 & 41.2 & 0.279 & 0.7 & & $\mathrm{G}$ & & & \\
\hline NY18 & $\begin{array}{l}\text { Treated waste- } \\
\text { water }\end{array}$ & 421206074100801 & WETL & 0.1 & 0.2 & 0.023 & 10.6 & & G & & & \\
\hline NY19 & $\begin{array}{l}\text { Treated waste- } \\
\text { water }\end{array}$ & 421259074142701 & AS & 43.6 & 97.0 & 0.504 & 0.5 & & $\mathrm{G}$ & & & \\
\hline NY21 & $\begin{array}{l}\text { Treated waste- } \\
\text { water }\end{array}$ & 412245073432601 & $\mathrm{RBC}$ & 0.9 & 1.7 & 0.464 & 27.5 & & $\mathrm{G}$ & & & G \\
\hline NY22 & $\begin{array}{l}\text { Treated waste- } \\
\text { water }\end{array}$ & 421443074574901 & $\mathrm{NCC}$ & 207.0 & 378 & 1.114 & 0.3 & & $\mathrm{G}$ & & & \\
\hline NY23 & $\begin{array}{l}\text { Treated waste- } \\
\text { water }\end{array}$ & 420821074391601 & $\mathrm{RBC}$ & 165.0 & 336 & 0.619 & 0.2 & & $\mathrm{G}$ & & & $\mathrm{C}$ \\
\hline NY23-U & $\begin{array}{l}\text { Untreated } \\
\text { wastewater }\end{array}$ & 420821074391699 & $\mathrm{RBC}$ & & & & & & & & & $\mathrm{C}$ \\
\hline NY23-S & Streamwater & 01413850 & & & & & & & & & & G \\
\hline NY24 & $\begin{array}{l}\text { Treated waste- } \\
\text { water }\end{array}$ & 420721074274901 & $\mathrm{RBC}$ & 12.4 & 28.1 & 0.774 & 2.7 & & G & & & \\
\hline NY28 & $\begin{array}{l}\text { Treated waste- } \\
\text { water }\end{array}$ & 411812073394501 & AS & 3.2 & 6.2 & 0.093 & 1.5 & & G & & & \\
\hline NY29 & $\begin{array}{l}\text { Treated waste- } \\
\text { water }\end{array}$ & 421811074165101 & AS & 40.6 & 79.3 & 0.580 & 0.7 & & $\mathrm{G}$ & & & \\
\hline NY30 & $\begin{array}{l}\text { Treated waste- } \\
\text { water }\end{array}$ & 423314075312701 & AS & 313.0 & 486.5 & 0.463 & 0.1 & G & $\mathrm{G}$ & G & G & \\
\hline NY30-S & Streamwater & 01505023 & & & & & & $\mathrm{G}$ & & & & \\
\hline NY31 & $\begin{array}{l}\text { Treated waste- } \\
\text { water }\end{array}$ & 423618075312001 & $\mathrm{AL}$ & 298.0 & 461.0 & 1.238 & 0.3 & G & G & G & $\mathrm{G}$ & $\mathrm{C}$ \\
\hline NY31-U & $\begin{array}{l}\text { Untreated } \\
\text { wastewater }\end{array}$ & 423618075312099 & $\mathrm{AL}$ & & & & & & & & & G \\
\hline NY31-S & Streamwater & 01505021 & & & & & & G & & & & G \\
\hline
\end{tabular}


Table 1. Description, treatment type, drainage area, estimated stream discharge (annual average), permitted effluent discharge, approximate dilution, and sampling schedule for 33 wastewater-treatment plants and receiving streams in New York, sampled during 2008-9.-Continued

[AL, aerated lagoon; AS, activated sludge; NCC, non-contact cooling; WETL, wetland-landfill; RBC, rotating biological contactor; SBR, sequential batch reactor; TF, trickling filter, G, grab sample; $\mathrm{C}$, 24-hour composite sample; ID, identifier; $\mathrm{mi}^{2}$, square miles; $\mathrm{ft}^{3} / \mathrm{s}$, cubic feet per second]

\begin{tabular}{|c|c|c|c|c|c|c|c|c|c|c|c|c|}
\hline \multirow{2}{*}{ Site code } & \multirow{2}{*}{ Sample type } & \multirow{2}{*}{ Station ID } & \multirow{2}{*}{$\begin{array}{c}\text { Treatment } \\
\text { type }\end{array}$} & \multirow{2}{*}{$\begin{array}{c}\text { Total } \\
\text { stream } \\
\text { drainage } \\
\text { area } \\
\left(\mathrm{mi}^{2}\right)\end{array}$} & \multirow{2}{*}{$\begin{array}{l}\text { Estimated } \\
\text { stream } \\
\text { discharge } \\
\left(\mathrm{ft}^{3} / \mathrm{s}\right)\end{array}$} & \multirow{2}{*}{$\begin{array}{c}\text { Permitted } \\
\text { effluent } \\
\text { discharge } \\
\left(\mathrm{ft}^{3} / \mathrm{s}\right)\end{array}$} & \multirow{2}{*}{$\begin{array}{l}\text { Approx- } \\
\text { imate } \\
\text { dilution } \\
\text { (percent) }\end{array}$} & \multicolumn{5}{|c|}{ Sample month and year } \\
\hline & & & & & & & & $7 / 08$ & $10 / 08$ & $1 / 09$ & $4 / 09$ & $10 / 09$ \\
\hline NY32 & $\begin{array}{l}\text { Treated waste- } \\
\text { water }\end{array}$ & 445337073281301 & SBR & 13.3 & 13.9 & 0.040 & 0.3 & G & $\mathrm{G}$ & G & G & G \\
\hline NY33 & $\begin{array}{l}\text { Treated waste- } \\
\text { water }\end{array}$ & 445952073223401 & AS & 3500.0 & 3816.0 & 3.094 & 0.1 & & & & & G \\
\hline
\end{tabular}

method used in this study is best described in Drewes and others (2005). Briefly, water-sample extracts were mixed with cell media at less than 1 percent, and a range of dilutions was tested by transferring the media to plates containing the MCF-7 cells. Each plate contained one column of negative controls and one row of $17 \beta$-estradiol (E2) spiked samples to assess possible interferences such as cytotoxicity. Each batch was run with a 15 point E2 calibration standard curve. The plates were incubated for 5 days and then fixed, stained, and read. Estrogenicity was calculated from the standard curve and corrected for the concentration of the extract, the dilution factor, and reported in 17ß-estradiol equivalents (E2 Eq). A mean value was calculated from the three replicates for each sample. The effective limit of detection was about 0.027 nanograms per liter (ng/L).

Chemical estrogenicity was determined using a model of estrogenicity of various hormones and EDCs relative to $17 \beta$-estradiol (Vajda and others, 2008) that was developed for a stream in Boulder, Colo., that received treated wastewater effluent. The model assumes that all sample compounds are linearly additive so that summing the concentrations of each constituent multiplied by its estrogen equivalence factor will produce an estimate of the total estrogenicity of the sample. The specific estrogen equivalence factors of individual model compounds were based on various published studies on compound-specific estrogenic activity (table 2). Hormones are weighted between 0.2 and 1.2 E2 Eq, whereas EDCs are weighted several orders of magnitude lower, between $3.6 \times 10^{-4}$ and $1.0 \times 10^{-7} \mathrm{E} 2 \mathrm{Eq}$. The model includes both minimum and maximum weights for selected hormones and EDCs; the mean of both values was used in all analyses. Equivalent minimum and maximum weights for estriol were taken from Drewes and others (2005). Chemical estrogenicity could not be calculated for several samples (mostly replicate samples) because they were missing either the hormone data or the EDC data.

The two measures of estrogenicity each have key advantages and disadvantages that can be used to address different questions. Biological estrogenicity of whole samples, as measured by e-screen assay, assesses the total estrogenic activity of whole samples without providing information on which specific components are causing the estrogenicity. This assay reflects the sum of effects of a host of compounds, so even those not known to be estrogenic are included. However, some samples may include compounds with antiestrogenic effects or compounds that interfere with each other. Chemical estrogenicity provides quantitative measures for specific contaminants in samples that have been shown to

Table 2. Hormones and non-hormone endocrine-disrupting compounds with low and high estradiol-equivalent weights used in calculating chemical estrogenicity.

[All values, except for Estriol are from Vajda and others (2008). The same low and high weight for Estriol is from Drewes and others (2005)]

\begin{tabular}{lcc}
\hline \multirow{2}{*}{\begin{tabular}{l} 
Compound \\
\multicolumn{2}{c}{ Hormones } & \multicolumn{2}{c}{ Estradiol-equivalent weights } \\
\cline { 2 - 3 } (E2 Eq)
\end{tabular}} \\
\cline { 2 - 3 } & 1.2 & High \\
\hline $17 \alpha$-Ethinylestradiol & 1.0 & 33 \\
$17 \beta$-Estradiol & 0.297 & 1.0 \\
Estriol & 0.2 & 0.297 \\
Estrone & 0.00007 & 0.8 \\
\hline \multicolumn{1}{c}{ Non-hormone endocrine-disrupting compounds } \\
\hline Bisphenol A & 0.000001 & 0.00016 \\
Diethoxynonylphenol (NP2EO) & 0.000001 & 0.000006 \\
Ethoxynonylphenol (NP1EO) & 0.000053 & 0.0036 \\
4-Nonylphenol (total, NP) & 0.00036 & 0.00036 \\
Diethoxyoctylphenol (OP2EO) & 0.00036 & 0.00036 \\
Ethoxyoctylphenol (OP1EO) & 0.00036 & 0.0005 \\
4-tert-Octylphenol & 0.0000001 & 0.0000001 \\
1,4-Dicholorbenzene & &
\end{tabular}


have estrogenic effects in tested organisms. Data for specific chemical contaminants, however, may not encompass all the natural and synthetic estrogenic compounds within the sample, and some EDCs may be present at levels that are below detection limits. The model used in this study contains several EDCs that were not detected in any of the samples. The model also excludes several other known or suspected EDCs that were detected in some of the samples.

Total suspended solids (TSS) or residue concentrations were analyzed using the standard (gravimetric) method 160.2 (USEPA, 1983a). Measurements of TSS were made only for samples collected prior to October 2009.

\section{Data Analyses}

Most hormone, EDC, and PPCP concentrations below respective detection limits were converted to a non-zero number below the lowest detected level in order to test for significant differences across seasons and WWTP types and to assess the inter-relations among estrogenicity and concentrations of hormones, EDCs, and PPCPs. Nondetectable limits for biological estrogenicity (e-screen values) were generally 0.027 or $0.030 \mathrm{ng} / \mathrm{L}$; all of these data were converted to one-half of the reported detection value. Failure to detect a compound does not necessarily imply it is absent; it implies that the concentration was less than the instrument detection limits. For plotting purposes, concentrations of other analytes originally reported as non-detected were also converted to a non-zero number less than the lowest detected level to facilitate plotting in log space.

\section{Quality Control}

Laboratory quality-control methods included laboratory blanks, field blanks, field replicates, and spikes with surrogate standards. Laboratory reagent blanks were used to assess potential sample contamination during routine analytical procedures. Field and laboratory blank samples were collected to assess possible contamination associated with water-handling and analytical procedures. Field blanks were collected at sampling sites, whereas analytical blanks were prepared in the laboratory by processing high-performance liquid chromatography-grade organic-free water (J.T. Baker Co.) using the same equipment that was used to collect and process effluent samples. Field replicates were used to assess the variability in detection and (or) measured concentrations for most chemical analyses. At least one field blank and one field replicate were collected during each of the five surveys (seasonal and treatment-efficacy surveys). Surrogate standards are chemicals that have properties similar to the analytes of interest but do not interfere with quantification of those analytes. Four and eight laboratory spikes were used to assess the recovery rates for compounds quantified using the SH4433 and SH4434 analyses, respectively.
Ten replicates (sample pairs) were analyzed using the SH4434 method; a comparison of each pair yielded 13 instances with compound detections in both samples. The median concentration difference between each pair of replicates was 5.4 percent, and the percent difference ranged from 0 to 23 percent. Four of the comparisons yielded a quantified concentration in one sample but a non-detect in the other; these four pairs had concentrations near the reporting limit, indicating that the lack of detection was due to the very low concentrations present in the replicate samples.

Seven samples were replicated for e-screen analysis; e-screen values were quantified for both samples in six of these replicate pairs, with a median difference of 5.3 percent and a range from 0 to 14 percent. No E2 Eq values were quantified for either sample in the seventh replicate pair.

Ten replicate pairs were assessed by using the SH4433 method, and 61 comparisons were made. The median percent difference for all constituent concentrations in replicate samples was 43 percent. This high difference is likely attributable to the relatively low concentrations (generally less than 0.4 microgram per liter $(\mu \mathrm{g} / \mathrm{L}))$ measured for most constituents. The percent differences ranged from 0 to 113 percent. Twenty-three other constituent comparisons included one replicate pair with a reported concentration in one sample but no quantified concentration in the other sample. About one-half of these samples had a detected, but not a quantified, concentration (for example, a concentration less than one-half of the reporting level), and the other onehalf had a detected value and a non-detected value.

Ten field blanks were collected and analyzed for various compounds using the SH4433 method, and no measured concentration exceeded the reporting limit for any compound. In rare cases, constituent concentrations were measured in blanks at levels that were less than 10 percent of the reporting limit. Although the very low concentrations indicated the possibility of very low-level contamination for some compounds, the reported environmental concentrations were greater than 10 times the concentrations reported in the blanks; therefore, this low-level contamination had no effect on data quality. Seven field-blank samples were analyzed using the SH4434 method, and there were no detections for any of the compounds. Measures of E2 Eq were below quantifiable limits (generally $0.030 \mathrm{ng} / \mathrm{L}$ ) for all field blanks subjected to e-screen analysis.

\section{Biological and Chemical Estrogenicity}

Biological estrogenicity in WWTP influents, effluents, and receiving streams varied widely among sites and sample periods or seasons (table 3). Though safe threshold concentrations of EDCs cannot be assumed (Wise and others, 2011), in this study, measured or estimated E2 Eq levels greater than $1.0 \mathrm{ng} / \mathrm{L}$ are considered to be estrogenic. $\mathrm{E} 2 \mathrm{Eq}$ levels of 0.1 to $1.0 \mathrm{ng} / \mathrm{L}$ are considered to be marginally 
Table 3. Biological and chemical estrogenicity of water samples collected, by season and treatment efficacy, from 33 wastewater-treatment plants in New York, during 2008-9.

[Estradiol-equivalent weight in nanograms per liter; ng/L, nanograms per liter]

\begin{tabular}{|c|c|c|c|c|c|}
\hline Site code & Sample type & Date & Time & $\begin{array}{c}\text { Mean biological } \\
\text { estrogenicity } \\
\text { (ng/L) }\end{array}$ & $\begin{array}{c}\text { Mean chemical } \\
\text { estrogenicity } \\
\text { (ng/L) }\end{array}$ \\
\hline \multicolumn{6}{|c|}{ A. Seasonal (summer) survey } \\
\hline NY2 & Treated wastewater & $7 / 14 / 2008$ & 1000 & $0.083^{\mathrm{a}}$ & 0.000000 \\
\hline NY3 & Treated wastewater & $7 / 15 / 2008$ & 1000 & 0.236 & 0.000000 \\
\hline NY31 & Treated wastewater & $7 / 15 / 2008$ & 1210 & 0.788 & 5.319000 \\
\hline NY31 & Treated wastewater-duplicate & $7 / 15 / 2008$ & 1211 & 0.839 & 5.435000 \\
\hline NY30 & Treated wastewater & $7 / 15 / 2008$ & 930 & $0.098^{\mathrm{a}}$ & 0.800000 \\
\hline NY8 & Treated wastewater & $7 / 15 / 2008$ & 1400 & 0.082 & 0.000000 \\
\hline NY32 & Treated wastewater & $7 / 14 / 2008$ & 1030 & $0.013^{\mathrm{b}}$ & 0.000000 \\
\hline NY32 & Treated wastewater-duplicate & $7 / 14 / 2008$ & 1031 & $0.013^{\mathrm{b}}$ & 0.000000 \\
\hline NY1 & Treated wastewater & $7 / 14 / 2008$ & 1300 & 1.345 & 3.788062 \\
\hline NY2-S & Streamwater & $7 / 14 / 2008$ & 1115 & $0.071^{\mathrm{a}}$ & 0.000000 \\
\hline NY3-S & Streamwater & $7 / 15 / 2008$ & 1100 & $0.044^{\mathrm{a}}$ & 0.417000 \\
\hline NY31-S & Streamwater & $7 / 15 / 2008$ & 1315 & $0.072^{\mathrm{a}}$ & 0.550000 \\
\hline NY30-S & Streamwater & $7 / 15 / 2008$ & 1100 & $0.090^{\mathrm{a}}$ & 0.364000 \\
\hline NY8-S & Streamwater & $7 / 15 / 2008$ & 1430 & $0.050^{\mathrm{a}}$ & 0.000000 \\
\hline NY32-S & Streamwater & $7 / 14 / 2008$ & 1400 & 0.054 & 0.351000 \\
\hline NY1-S & Streamwater & $7 / 14 / 2008$ & 1430 & $0.170^{\mathrm{a}}$ & 0.000000 \\
\hline \multicolumn{6}{|c|}{ B. Synoptic and seasonal (fall) survey } \\
\hline NY4 & Treated wastewater & $10 / 21 / 2008$ & 900 & 0.213 & 0.000001 \\
\hline NY5 & Treated wastewater & $10 / 22 / 2008$ & 930 & $0.045^{\mathrm{a}}$ & 0.183960 \\
\hline NY6 & Treated wastewater & $10 / 20 / 2008$ & 920 & 0.305 & 0.129575 \\
\hline NY11 & Treated wastewater & $10 / 28 / 2008$ & 1010 & 16.08 & 5.714221 \\
\hline NY7 & Treated wastewater & $10 / 28 / 2008$ & 940 & 0.167 & 0.000000 \\
\hline NY2 & Treated wastewater & $10 / 22 / 2008$ & 1100 & 0.102 & 0.000000 \\
\hline NY9 & Treated wastewater & $10 / 29 / 2008$ & 1150 & 0.096 & 0.000000 \\
\hline NY10 & Treated wastewater & $10 / 29 / 2008$ & 1120 & 0.712 & 3.294150 \\
\hline NY12 & Treated wastewater & $10 / 20 / 2008$ & 1230 & 0.062 & 0.000000 \\
\hline NY13 & Treated wastewater & $10 / 20 / 2008$ & 1130 & 0.069 & 0.000000 \\
\hline NY14 & Treated wastewater & $10 / 22 / 2008$ & 930 & 0.195 & 1.245000 \\
\hline NY15 & Treated wastewater & $10 / 28 / 2008$ & 850 & 1.593 & 2.996530 \\
\hline NY16 & Treated wastewater & $10 / 21 / 2008$ & 1100 & 0.473 & 0.635000 \\
\hline NY17 & Treated wastewater & $10 / 22 / 2008$ & 1100 & 0.181 & 0.000000 \\
\hline NY18 & Treated wastewater & $10 / 27 / 2008$ & 940 & $0.077^{\mathrm{a}}$ & 0.000000 \\
\hline NY3 & Treated wastewater & $10 / 20 / 2008$ & 1130 & $0.890^{\mathrm{a}}$ & 0.000000 \\
\hline NY3 & Treated wastewater-duplicate & $10 / 20 / 2008$ & 1131 & $0.880^{\mathrm{a}}$ & 0.000000 \\
\hline NY19 & Treated wastewater & $10 / 27 / 2008$ & 830 & $0.053^{\mathrm{a}}$ & 0.000000 \\
\hline NY20 & Treated wastewater & $10 / 20 / 2008$ & 1030 & $0.015^{\mathrm{b}}$ & 0.000000 \\
\hline NY21 & Treated wastewater & $10 / 29 / 2008$ & 1100 & 0.063 & 0.000000 \\
\hline NY21 & Treated wastewater-duplicate & $10 / 29 / 2008$ & 1101 & 0.063 & 0.000000 \\
\hline NY22 & Treated wastewater & $10 / 20 / 2008$ & 1205 & $0.015^{\mathrm{b}}$ & 0.000000 \\
\hline NY23 & Treated wastewater & $10 / 21 / 2008$ & 1010 & 0.637 & 0.615000 \\
\hline
\end{tabular}


Table 3. Biological and chemical estrogenicity of water samples collected, by season and treatment efficacy, from 33 wastewater-treatment plants in New York, during 2008-9.-Continued

[Estradiol-equivalent weight in nanograms per liter; ng/L, nanograms per liter]

\begin{tabular}{|c|c|c|c|c|c|}
\hline Site code & Sample type & Date & Time & $\begin{array}{l}\text { Mean biological } \\
\text { estrogenicity } \\
\text { (ng/L) }\end{array}$ & $\begin{array}{l}\text { Mean chemical } \\
\text { estrogenicity } \\
\text { (ng/L) }\end{array}$ \\
\hline \multicolumn{6}{|c|}{ B. Synoptic and seasonal (fall) survey-Continued } \\
\hline NY31 & Treated wastewater & $10 / 28 / 2008$ & 940 & 0.362 & 0.486500 \\
\hline NY30 & Treated wastewater & $10 / 28 / 2008$ & 900 & $0.036^{\mathrm{a}}$ & 0.000000 \\
\hline NY24 & Treated wastewater & $10 / 22 / 2008$ & 900 & $0.690^{\mathrm{a}}$ & 0.019780 \\
\hline NY25 & Treated wastewater & $10 / 21 / 2008$ & 1200 & 1.136 & 3.246981 \\
\hline NY26 & Treated wastewater & $10 / 21 / 2008$ & 800 & 0.079 & 0.000000 \\
\hline NY27 & Treated wastewater & $10 / 27 / 2008$ & 910 & 0.227 & 0.000000 \\
\hline NY8 & Treated wastewater & $10 / 21 / 2008$ & 1100 & $0.047^{\mathrm{a}}$ & 0.000000 \\
\hline NY28 & Treated wastewater & $10 / 29 / 2008$ & 850 & 0.058 & 0.000000 \\
\hline NY29 & Treated wastewater & $10 / 27 / 2008$ & 740 & 0.211 & 0.000002 \\
\hline NY32 & Treated wastewater & $10 / 22 / 2008$ & 940 & $0.015^{\mathrm{b}}$ & 0.000000 \\
\hline NY1 & Treated wastewater & $10 / 22 / 2008$ & 1300 & 3.296 & 6.815725 \\
\hline NY1 & Treated wastewater-duplicate & $10 / 22 / 2008$ & 1301 & 3.479 & 4.756909 \\
\hline \multicolumn{6}{|c|}{ C. Seasonal (winter) survey } \\
\hline NY2 & Treated wastewater & $1 / 12 / 2009$ & 1300 & 0.139 & 0.000000 \\
\hline NY3 & Treated wastewater & $1 / 14 / 2009$ & 930 & 2.308 & 0.000000 \\
\hline NY31 & Treated wastewater & $1 / 14 / 2009$ & 1020 & 0.717 & 0.780410 \\
\hline NY30 & Treated wastewater & $1 / 14 / 2009$ & 920 & 0.129 & 0.000000 \\
\hline NY30 & Treated wastewater & $1 / 14 / 2009$ & 931 & 0.145 & 0.000000 \\
\hline NY8 & Treated wastewater & $1 / 15 / 2009$ & 1000 & 0.209 & 0.000000 \\
\hline NY32 & Treated wastewater & $1 / 13 / 2009$ & 1100 & $0.015^{\mathrm{b}}$ & 0.000000 \\
\hline NY1 & Treated wastewater & $1 / 15 / 2009$ & 1330 & 1.854 & 3.591910 \\
\hline \multicolumn{6}{|c|}{ D. Seasonal (spring) survey } \\
\hline NY2 & Treated wastewater & $4 / 29 / 2009$ & 700 & 1.723 & 0.000001 \\
\hline NY3 & Treated wastewater-duplicate & $4 / 28 / 2009$ & 1230 & 3.418 & 0.215860 \\
\hline NY3 & Treated wastewater & $4 / 28 / 2009$ & 1231 & 3.584 & 0.000000 \\
\hline NY31 & Treated wastewater & $4 / 28 / 2009$ & 1000 & 2.800 & 0.000000 \\
\hline NY30 & Treated wastewater & $4 / 28 / 2009$ & 900 & 0.211 & 0.000000 \\
\hline NY8 & Treated wastewater & 4/29/2009 & 1430 & 0.504 & 0.846995 \\
\hline NY32 & Treated wastewater & $4 / 28 / 2009$ & 1030 & $0.015^{\mathrm{b}}$ & 6.432000 \\
\hline NY1 & Treated wastewater & $4 / 29 / 2009$ & 1200 & 1.498 & 3.080000 \\
\hline \multicolumn{6}{|c|}{ E. Treatment-efficacy survey } \\
\hline NY11 & Treated wastewater & $9 / 29 / 2009$ & 0830 & 1.248 & 3.452540 \\
\hline NY11 & Treated wastewater & $9 / 29 / 2009$ & 0831 & 1.079 & 3.418030 \\
\hline NY2 & Treated wastewater & 9/30/2009 & 0200 & 0.217 & 0.000000 \\
\hline NY10 & Treated wastewater & 9/29/2009 & 1330 & 0.754 & 1.030200 \\
\hline NY15 & Treated wastewater & $10 / 7 / 2009$ & 1300 & 0.088 & 0.000000 \\
\hline NY15 & Treated wastewater-duplicate & $10 / 7 / 2009$ & 1301 & 0.167 & 0.000000 \\
\hline NY3 & Treated wastewater-duplicate & $10 / 14 / 2009$ & 2340 & 0.436 & 0.000000 \\
\hline NY3 & Treated wastewater & $10 / 14 / 2009$ & 2330 & 0.463 & 0.000000 \\
\hline NY21 & Treated wastewater & $10 / 6 / 2009$ & 1400 & $0.043^{\mathrm{a}}$ & 0.000000 \\
\hline
\end{tabular}


Table 3. Biological and chemical estrogenicity of water samples collected, by season and treatment efficacy, from 33 wastewater-treatment plants in New York, during 2008-9.-Continued

[Estradiol-equivalent weight in nanograms per liter; ng/L, nanograms per liter]

\begin{tabular}{|c|c|c|c|c|c|}
\hline Site code & Sample type & Date & Time & $\begin{array}{c}\text { Mean biological } \\
\text { estrogenicity } \\
\text { (ng/L) }\end{array}$ & $\begin{array}{c}\text { Mean chemical } \\
\text { estrogenicity } \\
\text { (ng/L) }\end{array}$ \\
\hline \multicolumn{6}{|c|}{ E. Treatment-efficacy survey-Continued } \\
\hline NY23 & Treated wastewater & $10 / 21 / 2009$ & 2200 & 1.590 & 0.610000 \\
\hline NY31 & Treated wastewater & $10 / 19 / 2009$ & 2155 & 0.398 & 5.161200 \\
\hline NY25 & Treated wastewater & $10 / 13 / 2009$ & 0915 & 0.787 & 0.141800 \\
\hline NY25 & Treated wastewater & $10 / 13 / 2009$ & 0916 & 0.747 & 0.000000 \\
\hline NY33 & Treated wastewater & $10 / 7 / 2009$ & 1030 & 0.758 & 0.000000 \\
\hline NY8 & Treated wastewater & $10 / 14 / 2009$ & 0930 & $0.030^{\mathrm{a}}$ & 0.000000 \\
\hline NY32 & Treated wastewater & $10 / 7 / 2009$ & 1200 & $0.015^{\mathrm{b}}$ & 0.000000 \\
\hline NY1 & Treated wastewater & $10 / 7 / 2009$ & 0030 & 1.721 & 12.417100 \\
\hline NY11-U & Untreated wastewater & $9 / 28 / 2009$ & 2030 & 49.286 & 83.285588 \\
\hline NY2-U & Untreated wastewater & $9 / 28 / 2009$ & 1900 & 44.517 & 56.605046 \\
\hline NY3-U & Untreated wastewater & $10 / 12 / 2009$ & 1930 & 46.325 & 23.845827 \\
\hline NY23-U & Untreated wastewater & $10 / 20 / 2009$ & 2200 & 60.332 & 84.259572 \\
\hline NY31-U & Untreated wastewater & $10 / 19 / 2009$ & 1000 & 14.288 & 88.640865 \\
\hline NY1-U & Untreated wastewater & $10 / 5 / 2009$ & 1930 & 36.580 & 58.573056 \\
\hline NY11-S & Streamwater & 9/29/2009 & 1400 & $0.025^{\mathrm{b}}$ & 1.401840 \\
\hline NY2-S & Streamwater & $9 / 30 / 2009$ & 1400 & $0.081^{\mathrm{a}}$ & 0.000000 \\
\hline NY3-S & Streamwater & $10 / 13 / 2009$ & 1000 & $0.053^{\mathrm{a}}$ & 1.211760 \\
\hline NY23-S & Streamwater & $10 / 18 / 2009$ & 1000 & $0.037^{\mathrm{a}}$ & 0.000000 \\
\hline NY31-S & Streamwater & $10 / 19 / 2009$ & 1100 & 0.057 & 0.000000 \\
\hline NY32-S & Streamwater & $10 / 7 / 2009$ & 1245 & 0.398 & 0.000000 \\
\hline NY32-S & Streamwater & $10 / 7 / 2009$ & 1215 & 0.173 & 0.000000 \\
\hline NY1-S & Streamwater & $10 / 6 / 2009$ & 1100 & 0.879 & 1.259410 \\
\hline
\end{tabular}

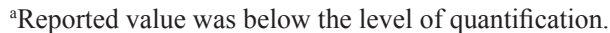

${ }^{b}$ Value was below level of detection and was estimated as one-half the detection limit, which varied from 0.027 to $0.05 \mathrm{ng} / \mathrm{L}$. 
estrogenic and E2 Eq levels less than $0.1 \mathrm{ng} / \mathrm{L}$, nonestrogenic. Biological estrogenicity was generally very high (14.3 to $60.3 \mathrm{ng} / \mathrm{L}$, table $3 \mathrm{E}$ ) in WWTP influents (untreated wastewater) it was usually less than the detection limit or low $(0.025$ to $0.879 \mathrm{ng} / \mathrm{L}$, table $3 \mathrm{~A}, 3 \mathrm{E})$ in receiving streams (streamwater). Biological estrogenicity ranged from less than detection (typically $0.027 \mathrm{ng} / \mathrm{L}$ ) to a high of $16.08 \mathrm{ng} / \mathrm{L}$ (table 3) with a median of $0.22 \mathrm{ng} / \mathrm{L}$ in effluents (treated wastewater). Seventeen effluent samples from eight WWTPs had biological estrogenicity higher than $1.0 \mathrm{ng} / \mathrm{L}$ (table 3, fig. 2). The biological estrogenicity of many effluent samples was relatively low; however, estrogenicity at two sites with numerous samples (NY1 and NY11) was always high (greater than $1.0 \mathrm{ng} / \mathrm{L}$ ), and more than one-half of all samples were at least marginally estrogenic (that is greater than $0.1 \mathrm{ng} / \mathrm{L}$ ).

Seasonal variations in biological estrogenicity were generally similar among effluent samples from seven WWTPs (fig. 3). Although the magnitude of measured E2 Eq concentrations differed among the sites, the sequence (from low to high) of E2 Eq concentrations was relatively consistent across the five surveys, and except for NY1, concentrations were highest during spring and lower during fall and summer. Levels of E2 Eq in the effluent at NY1 were atypical; they were highest during fall (October 2008) and consistently above $1.0 \mathrm{ng} / \mathrm{L}$ during the other periods. Except for the NY31 January sample, the E2 Eq concentrations from all other sites, sampled before and after the April 2009 survey, were lower than $1.0 \mathrm{ng} / \mathrm{L}$. Differences in the type of process used to treat wastewaters at each plant could explain their overall rankings and the atypical seasonal trend noted at NY1.

Estimates of chemical estrogenicity (mean values calculated from low and high estimates for measured hormones and non-hormone EDCs) in WWTP influents, effluents, and receiving streams, like biological values, varied widely among sites and seasons (tables 3,4 ). The chemical estrogenicity of WWTP influents was consistently high and ranged from 24.8 to $88.6 \mathrm{ng} / \mathrm{L} \mathrm{E} 2 \mathrm{Eq}$ (tables $3 \mathrm{E}, 4$ ). The chemical estrogenicity in all stream samples, however, was always less than $1.40 \mathrm{ng} / \mathrm{L}$ (tables $3 \mathrm{~A}, 3 \mathrm{E}, 4$ ). The chemical estrogenicity of all effluent samples ranged from 0 to $12.42 \mathrm{ng} / \mathrm{L} \mathrm{E} 2 \mathrm{Eq}$ (tables 3, 4, fig. 4). Sixteen effluent samples from eight WWTPs had chemical estrogenicity greater than $1.0 \mathrm{ng} / \mathrm{L}$.

Mean estimated levels of chemical estrogenicity were sometimes much lower than the mean measures of biological (e-screen) estrogenicity within spilt samples. When biological estrogenicity was compared to chemical estrogenicity (fig. 5), two general clusters or groupings of values became obvious.

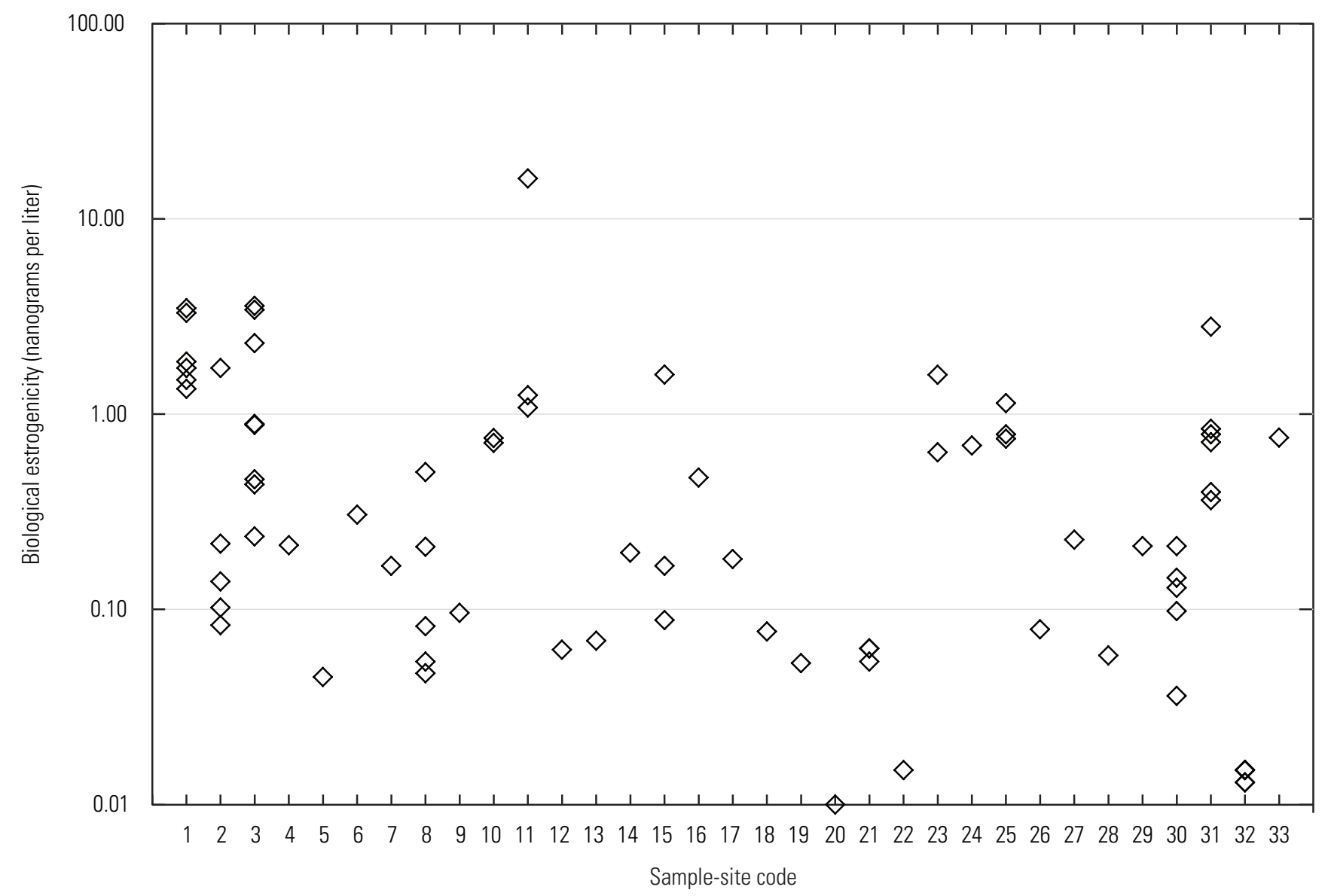

Figure 2. Biological estrogenicity measured in all effluent samples collected at 33 wastewater-treatment plants in New York, 2008-9. Sites sampled more than once are denoted by multiple values. 


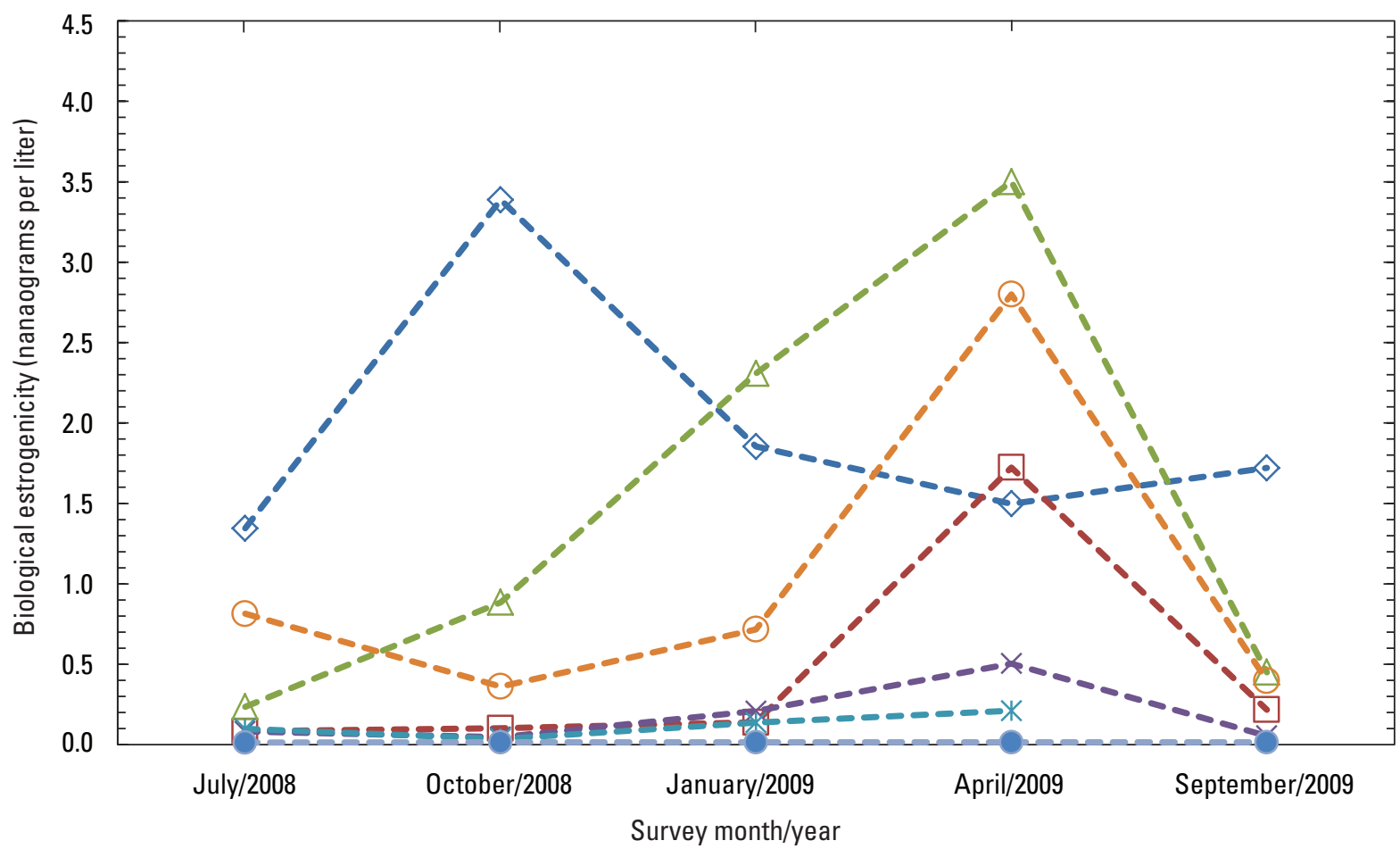

EXPLANATION

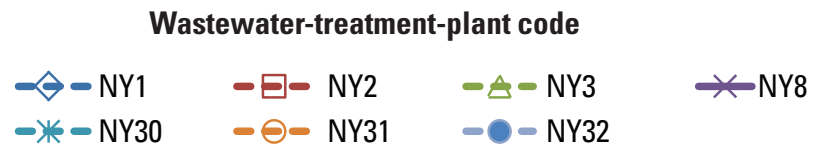

Figure 3. Biological estrogenicity in effluent samples collected at seven wastewater-treatment plants in New York during seasonal surveys, 2008-9.

In the first group (darker shaded region to the right side of figure 5), the values for estimated chemical and measured biological estrogenicity are relatively similar, or at least comparable to each other, and the points fall close to the 1-to-1 line. These findings indicate that the results from the two methods are similar and that the hormones and nonhormone EDCs in these effluents accurately characterized the total estrogenicity of the effluent as quantified by the e-screen assay (biological estrogenicity). In the second group, (lighter shaded region to the left side of figure 5) measures of biological estrogenicity were usually much higher than estimated chemical estrogenicity. The poor relation indicates that the estrogenicity in several effluents may be affected by additional, and possibly unknown, EDCs or that use of average of low and high predictions to quantify chemical estrogenicity is not valid.

The type of WWTP process appears to have a large effect on the efficacy of removal of estrogenic compounds and, thus, the estrogenicity that was measured in the various effluents. Effluent samples from WWTPs using either an aerated lagoon (AL) or trickling filter (TF) had higher levels of biological estrogenicity than other types of treatments. Estrogenicity was intermediate in the effluents from WWTPs using rotating biological contactors (RBCs) or activated sludge (AS) and lowest in effluents using sequential batch reactors (SBR) (fig. 6A). The biological estrogenicity levels of effluents from the single wetland (WETL), NY18, and two non-contact cooling (NCC), NY20 and NY22, were much less than $0.1 \mathrm{ng} / \mathrm{L}$ or the detection limit (table 3, fig. 6A). Measures of biological estrogenicity in untreated influents for six WWTPs ranged from 14.3 to $60.3 \mathrm{ng} / \mathrm{L}$ and averaged $41.9 \mathrm{ng} / \mathrm{L}$, whereas biological estrogenicity in their treated effluents ranged from 0.217 to $1.721 \mathrm{ng} / \mathrm{L}$ and averaged $0.9 \mathrm{ng} / \mathrm{L}$ (table 3E). Estimated removal efficiencies (influent E2 Eq effluent E2 Eq, divided by influent E2 Eq), using biological estrogenicity data, averaged 95.3 percent at one trickling filter (TF) plant, 97.2 percent at one aerated lagoon plant (AL), 97.5 percent at two RBC plants, 99.3 percent at two activated sludge (AS) plants, and 97.7 percent (overall) at all six plants. Although the range in efficiencies among the four plant types was small, the mean removal efficacy (for the four treatment types) could account for 78 and 95 percent of the variability in 
Table 4. Concentrations of common endocrine-disrupting compounds, hormones, bisphenol A, and estimated estrogenicity for samples collected from wastewater-treatment plant effluents and influents, and receiving streams, in New York, 2008-9.

[Concentrations are in nanograms per liter (ng/L), except where noted otherwise. na, not determined; Sample medium: WE, effluent; WEQ, replicate; WU, influent; WS, streamwater]

\begin{tabular}{|c|c|c|c|c|c|c|c|c|c|}
\hline \multirow[b]{2}{*}{$\begin{array}{l}\text { Site } \\
\text { code }\end{array}$} & \multirow[b]{2}{*}{$\begin{array}{l}\text { Sample } \\
\text { medium }\end{array}$} & \multirow[b]{2}{*}{$\begin{array}{l}\text { Sample } \\
\text { date }\end{array}$} & \multicolumn{7}{|c|}{ Endocrine-disrupting compounds } \\
\hline & & & 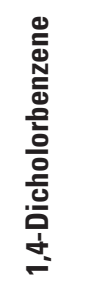 & 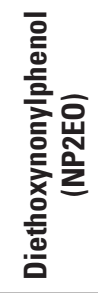 & 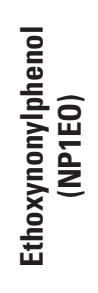 & 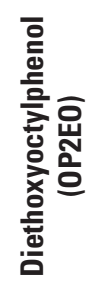 & 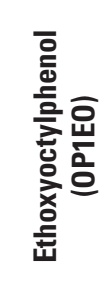 & 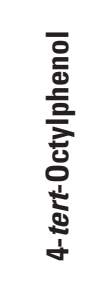 & 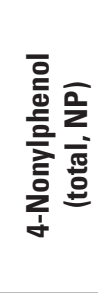 \\
\hline \multicolumn{10}{|c|}{ Effluent samples } \\
\hline NY1 & WE & $7 / 14 / 2008$ & 0 & 3.55 & 0 & 0 & 0 & 0 & 0.921 \\
\hline NY1 & WE & $10 / 22 / 2008$ & 0 & 7.71 & 2.01 & 1.05 & 0.696 & 0.316 & 1.86 \\
\hline NY1 & WEQ & $10 / 22 / 2008$ & 0 & 3.93 & 1.04 & 0.658 & 0.373 & 0.18 & 0.919 \\
\hline NY1 & WE & $1 / 14 / 2009$ & 0 & 2.28 & 0 & 0 & 0 & 0 & 0 \\
\hline NY1 & WE & $4 / 28 / 2009$ & 0 & 0 & 0 & 0 & 0 & 0 & 0 \\
\hline NY1 & WE & $10 / 7 / 2009$ & 0 & 0 & 0 & 0 & 0 & 0 & 0 \\
\hline NY1 & WEQ & $10 / 7 / 2009$ & 0 & 0 & 0 & 0.279 & 0.227 & 0 & 0 \\
\hline NY2 & WE & $7 / 14 / 2008$ & 0 & 0 & 0 & 0 & 0 & 0 & 0 \\
\hline NY2 & WE & $10 / 22 / 2008$ & 0 & 0 & 0 & 0 & 0 & 0 & 0 \\
\hline NY2 & WE & $1 / 12 / 2009$ & 0 & 0 & 0 & 0 & 0 & 0 & 0 \\
\hline NY2 & WE & 4/28/2009 & 0.124 & 0 & 0 & 0 & 0 & 0 & 0 \\
\hline NY2 & WE & $9 / 30 / 2009$ & 0 & 0 & 0 & 0 & 0 & 0 & 0 \\
\hline NY2 & WEQ & 9/30/2009 & 0 & 0 & 0 & 0 & 0 & 0 & 0 \\
\hline NY3 & WE & $7 / 15 / 2008$ & 0 & 0 & 0 & 0 & 0 & 0 & 0 \\
\hline NY3 & WE & $10 / 20 / 2008$ & 0 & 0 & 0 & 0 & 0 & 0 & 0 \\
\hline NY3 & WEQ & $10 / 20 / 2008$ & 0 & 0 & 0 & 0 & 0 & 0 & 0 \\
\hline NY3 & WE & $1 / 13 / 2009$ & 0 & 0 & 0 & 0 & 0 & 0 & 0 \\
\hline NY3 & WE & 4/27/2009 & 0 & 0 & 0 & 0 & 0 & 0.502 & 0 \\
\hline NY3 & WEQ & $4 / 27 / 2009$ & 0 & 0 & 0 & 0 & 0 & 0 & 0 \\
\hline NY3 & WE & $10 / 14 / 2009$ & 0 & 0 & 0 & 0 & 0 & 0 & 0 \\
\hline NY3 & WEQ & $10 / 14 / 2009$ & 0 & 0 & 0 & 0 & 0 & 0 & 0 \\
\hline NY4 & WE & $10 / 21 / 2008$ & 0.105 & 0 & 0 & 0 & 0 & 0 & 0 \\
\hline NY5 & WE & $10 / 22 / 2008$ & 0 & 0 & 0 & 0.236 & 0.275 & 0 & 0 \\
\hline NY6 & WE & $10 / 20 / 2008$ & 0 & 3.91 & 1.05 & 0.183 & 0.136 & 0 & 0 \\
\hline NY7 & WE & $10 / 28 / 2008$ & 0 & 0 & 0 & 0 & 0 & 0 & 0 \\
\hline NY8 & WE & $7 / 15 / 2008$ & 0 & 0 & 0 & 0 & 0 & 0 & 0 \\
\hline NY8 & WE & $10 / 21 / 2008$ & 0 & 0 & 0 & 0 & 0 & 0 & 0 \\
\hline NY8 & WE & $1 / 14 / 2009$ & 0 & 0 & 0 & 0 & 0 & 0 & 0 \\
\hline NY8 & WE & 4/28/2009 & 0 & 0 & 0 & 0 & 0 & 0 & 0 \\
\hline NY8 & WE & $10 / 14 / 2009$ & 0 & 0 & 0 & 0 & 0 & 0 & 0 \\
\hline NY9 & WE & $10 / 29 / 2008$ & 0 & 0 & 0 & 0 & 0 & 0 & 0 \\
\hline NY10 & WE & $10 / 29 / 2008$ & 0 & 0 & 0 & 0 & 0 & 0 & 1.1 \\
\hline NY10 & WE & $11 / 5 / 2008$ & 0 & 0 & 0 & 0 & 0 & 0 & 0 \\
\hline NY10 & WE & 9/29/2009 & 0 & 0 & 0 & 0 & 0 & 0 & 0 \\
\hline NY11 & WE & $10 / 28 / 2008$ & 0.117 & 2 & 1.09 & 0.188 & 0.211 & 0.192 & 1.02 \\
\hline
\end{tabular}


Table 4. Concentrations of common endocrine-disrupting compounds, hormones, bisphenol A, and estimated estrogenicity for samples collected from wastewater-treatment plant effluents and influents, and receiving streams, in New York, 2008-9. —Continued

[Concentrations are in nanograms per liter (ng/L), except where noted otherwise. na, not determined; Sample medium: WE, effluent; WEQ, replicate; WU, influent; WS, streamwater]

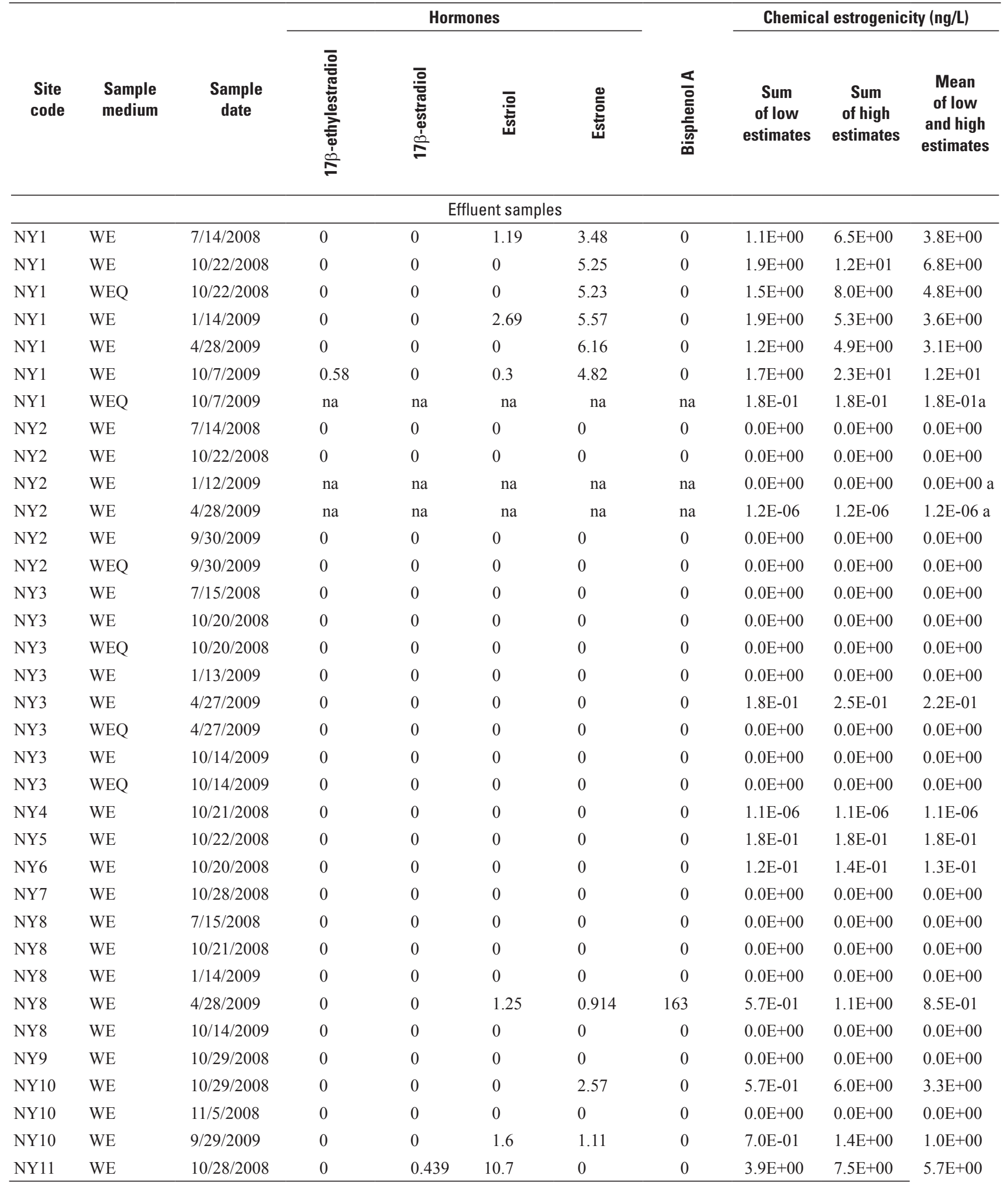


Table 4. Concentrations of common endocrine-disrupting compounds, hormones, bisphenol A, and estimated estrogenicity for samples collected from wastewater-treatment plant effluents and influents, and receiving streams, in New York, 2008-9. - Continued

[Concentrations are in nanograms per liter (ng/L), except where noted otherwise. na, not determined; Sample medium: WE, effluent; WEQ, replicate; WU, influent; WS, streamwater]

\begin{tabular}{|c|c|c|c|c|c|c|c|c|c|}
\hline \multirow[b]{2}{*}{$\begin{array}{l}\text { Site } \\
\text { code }\end{array}$} & \multirow[b]{2}{*}{$\begin{array}{l}\text { Sample } \\
\text { medium }\end{array}$} & \multirow[b]{2}{*}{$\begin{array}{c}\text { Sample } \\
\text { date }\end{array}$} & \multicolumn{7}{|c|}{ Endocrine-disrupting compounds } \\
\hline & & & 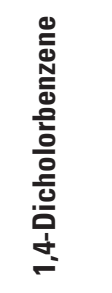 & 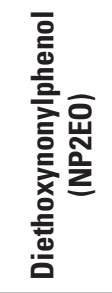 & 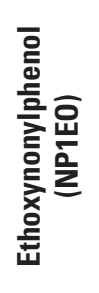 & 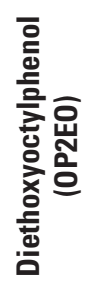 & 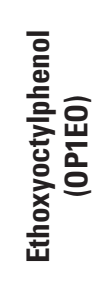 & 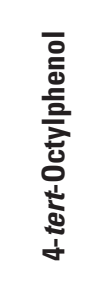 & 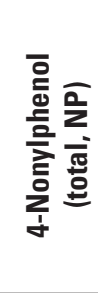 \\
\hline \multicolumn{10}{|c|}{ Effluent samples-Continued } \\
\hline NY11 & WE & $9 / 29 / 2009$ & 0 & 0 & 0 & 0 & 0 & 0 & 0 \\
\hline NY11 & WEQ & 9/29/2009 & na & na & na & na & na & na & na \\
\hline NY12 & $\mathrm{WE}$ & $10 / 20 / 2008$ & 0 & 0 & 0 & 0 & 0 & 0 & 0 \\
\hline NY13 & WE & $10 / 20 / 2008$ & 0 & 0 & 0 & 0 & 0 & 0 & 0 \\
\hline NY14 & WE & $10 / 22 / 2008$ & 0 & 0 & 0 & 0 & 0 & 0 & 0 \\
\hline NY15 & WE & $10 / 28 / 2008$ & 0 & 0 & 0 & 0 & 0 & 0 & 0 \\
\hline NY15 & WE & $10 / 7 / 2009$ & 0 & 0 & 0 & 0 & 0 & 0 & 0 \\
\hline NY15 & WEQ & $10 / 7 / 2009$ & na & na & na & na & na & na & na \\
\hline NY16 & $\mathrm{WE}$ & $10 / 21 / 2008$ & 0 & 0 & 0 & 0 & 0 & 0 & 0 \\
\hline NY17 & WE & $10 / 22 / 2008$ & 0 & 0 & 0 & 0 & 0 & 0 & 0 \\
\hline NY18 & WE & $10 / 27 / 2008$ & 0 & 0 & 0 & 0 & 0 & 0 & 0 \\
\hline NY19 & WE & $10 / 27 / 2008$ & 0 & 0 & 0 & 0 & 0 & 0 & 0 \\
\hline NY20 & WE & $10 / 20 / 2008$ & 0 & 0 & 0 & 0 & 0 & 0 & 0 \\
\hline NY21 & WE & $10 / 29 / 2008$ & 0 & 0 & 0 & 0 & 0 & 0 & 0 \\
\hline NY21 & WEQ & $10 / 29 / 2008$ & 0 & 0 & 0 & 0 & 0 & 0 & 0 \\
\hline NY21 & $\mathrm{WE}$ & $10 / 6 / 2009$ & 0 & 0 & 0 & 0 & 0 & 0 & 0 \\
\hline NY22 & WE & $10 / 20 / 2008$ & 0 & 0 & 0 & 0 & 0 & 0 & 0 \\
\hline NY23 & WE & $10 / 21 / 2008$ & 0 & 0 & 0 & 0 & 0 & 0 & 0 \\
\hline NY23 & WE & $10 / 21 / 2009$ & 0 & 0 & 0 & 0 & 0 & 0 & 0 \\
\hline NY24 & WE & $10 / 22 / 2008$ & 0 & 0 & 0 & 0 & 0 & 0 & 0 \\
\hline NY25 & WE & $10 / 21 / 2008$ & 0.141 & 0 & 0 & 0 & 0 & 0 & 0 \\
\hline NY25 & WE & $10 / 13 / 2009$ & 19 & 0 & 0 & 0.213 & 0 & 0.151 & 0 \\
\hline NY25 & WEQ & $10 / 13 / 2009$ & na & na & na & na & na & na & na \\
\hline NY26 & WE & $10 / 21 / 2008$ & 0 & 0 & 0 & 0 & 0 & 0 & 0 \\
\hline NY27 & WE & $10 / 27 / 2008$ & 0 & 0 & 0 & 0 & 0 & 0 & 0 \\
\hline NY28 & WE & $10 / 29 / 2008$ & 0 & 0 & 0 & 0 & 0 & 0 & 0 \\
\hline NY29 & WE & $10 / 27 / 2008$ & 0.153 & 0 & 0 & 0 & 0 & 0 & 0 \\
\hline NY30 & WE & $7 / 15 / 2008$ & 0 & 0 & 0 & 0 & 0 & 0 & 0 \\
\hline NY30 & WE & $10 / 28 / 2008$ & 0 & 0 & 0 & 0 & 0 & 0 & 0 \\
\hline NY30 & $\mathrm{WE}$ & $1 / 13 / 2009$ & 0 & 0 & 0 & 0 & 0 & 0 & 0 \\
\hline NY30 & WEQ & $1 / 13 / 2009$ & 0 & 0 & 0 & 0 & 0 & 0 & 0 \\
\hline NY30 & $\mathrm{WE}$ & 4/27/2009 & 0 & 0 & 0 & 0 & 0 & 0 & 0 \\
\hline NY31 & $\mathrm{WE}$ & $7 / 15 / 2008$ & 0 & 0 & 0 & 0 & 0 & 0 & 0 \\
\hline NY31 & WEQ & $7 / 15 / 2008$ & 0 & 0 & 0 & 0 & 0 & 0 & 0 \\
\hline NY31 & $\mathrm{WE}$ & $10 / 28 / 2008$ & 0 & 0 & 0 & 0 & 0 & 0 & 0 \\
\hline
\end{tabular}


Table 4. Concentrations of common endocrine-disrupting compounds, hormones, bisphenol A, and estimated estrogenicity for samples collected from wastewater-treatment plant effluents and influents, and receiving streams, in New York, 2008-9. - Continued

[Concentrations are in nanograms per liter (ng/L), except where noted otherwise. na, not determined; Sample medium: WE, effluent; WEQ, replicate; WU, influent; WS, streamwater]

\begin{tabular}{|c|c|c|c|c|c|c|c|c|c|c|}
\hline $\begin{array}{l}\text { Site } \\
\text { code }\end{array}$ & $\begin{array}{l}\text { Sample } \\
\text { medium }\end{array}$ & $\begin{array}{c}\text { Sample } \\
\text { date }\end{array}$ & \multicolumn{4}{|c|}{ Hormones } & $\begin{array}{l}\frac{\square}{0} \\
\frac{\overline{0}}{0} \\
\frac{\bar{c}}{0} \\
\frac{0}{\infty}\end{array}$ & \multicolumn{3}{|c|}{ Chemical estrogenicity (ng/L) } \\
\hline \multicolumn{11}{|c|}{ Effluent samples-Continued } \\
\hline NY11 & WE & $9 / 29 / 2009$ & 0 & 0.552 & 1.82 & 4.72 & 0 & $2.0 \mathrm{E}+00$ & $4.9 \mathrm{E}+00$ & $3.5 \mathrm{E}+00$ \\
\hline NY11 & WEQ & 9/29/2009 & 0 & 0.467 & 1.99 & 4.72 & 0 & $2.0 \mathrm{E}+00$ & $4.8 \mathrm{E}+00$ & $3.4 \mathrm{E}+00 \mathrm{~b}$ \\
\hline NY12 & WE & $10 / 20 / 2008$ & 0 & 0 & 0 & 0 & 0 & $0.0 \mathrm{E}+00$ & $0.0 \mathrm{E}+00$ & $0.0 \mathrm{E}+00$ \\
\hline NY13 & WE & $10 / 20 / 2008$ & 0 & 0 & 0 & 0 & 0 & $0.0 \mathrm{E}+00$ & $0.0 \mathrm{E}+00$ & $0.0 \mathrm{E}+00$ \\
\hline NY15 & WEQ & $10 / 7 / 2009$ & 0 & 0 & 0 & 0 & 0 & $0.0 \mathrm{E}+00$ & $0.0 \mathrm{E}+00$ & $0.0 \mathrm{E}+00 \mathrm{~b}$ \\
\hline NY16 & WE & $10 / 21 / 2008$ & 0 & 0 & 0 & 1.27 & 0 & $2.5 \mathrm{E}-01$ & $1.0 \mathrm{E}+00$ & $6.4 \mathrm{E}-01$ \\
\hline NY17 & WE & $10 / 22 / 2008$ & 0 & 0 & 0 & 0 & 0 & $0.0 \mathrm{E}+00$ & $0.0 \mathrm{E}+00$ & $0.0 \mathrm{E}+00$ \\
\hline NY18 & WE & $10 / 27 / 2008$ & 0 & 0 & 0 & 0 & 0 & $0.0 \mathrm{E}+00$ & $0.0 \mathrm{E}+00$ & $0.0 \mathrm{E}+00$ \\
\hline NY19 & WE & $10 / 27 / 2008$ & 0 & 0 & 0 & 0 & 0 & $0.0 \mathrm{E}+00$ & $0.0 \mathrm{E}+00$ & $0.0 \mathrm{E}+00$ \\
\hline NY20 & WE & $10 / 20 / 2008$ & 0 & 0 & 0 & 0 & 0 & $0.0 \mathrm{E}+00$ & $0.0 \mathrm{E}+00$ & $0.0 \mathrm{E}+00$ \\
\hline NY21 & WE & $10 / 29 / 2008$ & 0 & 0 & 0 & 0 & 0 & $0.0 \mathrm{E}+00$ & $0.0 \mathrm{E}+00$ & $0.0 \mathrm{E}+00$ \\
\hline NY21 & WEQ & $10 / 29 / 2008$ & 0 & 0 & 0 & 0 & 0 & $0.0 \mathrm{E}+00$ & $0.0 \mathrm{E}+00$ & $0.0 \mathrm{E}+00$ \\
\hline NY25 & WE & $10 / 13 / 2009$ & 0 & 0 & 0 & 0 & 0 & $1.3 \mathrm{E}-01$ & $1.5 \mathrm{E}-01$ & $1.4 \mathrm{E}-01$ \\
\hline NY25 & WEQ & $10 / 13 / 2009$ & 0 & 0 & 0 & 0 & 0 & $0.0 \mathrm{E}+00$ & $0.0 \mathrm{E}+00$ & $0.0 \mathrm{E}+00 \mathrm{~b}$ \\
\hline NY26 & WE & $10 / 21 / 2008$ & 0 & 0 & 0 & 0 & 0 & $0.0 \mathrm{E}+00$ & $0.0 \mathrm{E}+00$ & $0.0 \mathrm{E}+00$ \\
\hline NY27 & WE & $10 / 27 / 2008$ & 0 & 0 & 0 & 0 & 0 & $0.0 \mathrm{E}+00$ & $0.0 \mathrm{E}+00$ & $0.0 \mathrm{E}+00$ \\
\hline NY28 & WE & $10 / 29 / 2008$ & 0 & 0 & 0 & 0 & 0 & $0.0 \mathrm{E}+00$ & $0.0 \mathrm{E}+00$ & $0.0 \mathrm{E}+00$ \\
\hline NY29 & WE & $10 / 27 / 2008$ & 0 & 0 & 0 & 0 & 0 & $1.5 \mathrm{E}-06$ & $1.5 \mathrm{E}-06$ & $1.5 \mathrm{E}-06$ \\
\hline NY30 & WE & $7 / 15 / 2008$ & 0 & 0 & 0 & 1.6 & 0 & $3.2 \mathrm{E}-01$ & $1.3 \mathrm{E}+00$ & $8.0 \mathrm{E}-01$ \\
\hline NY30 & WE & $10 / 28 / 2008$ & 0 & 0 & 0 & 0 & 0 & $0.0 \mathrm{E}+00$ & $0.0 \mathrm{E}+00$ & $0.0 \mathrm{E}+00$ \\
\hline NY30 & WE & $1 / 13 / 2009$ & 0 & 0 & 0 & 0 & 0 & $0.0 \mathrm{E}+00$ & $0.0 \mathrm{E}+00$ & $0.0 \mathrm{E}+00$ \\
\hline NY30 & WEQ & $1 / 13 / 2009$ & 0 & 0 & 0 & 0 & 0 & $0.0 \mathrm{E}+00$ & $0.0 \mathrm{E}+00$ & $0.0 \mathrm{E}+00$ \\
\hline NY30 & WE & $4 / 27 / 2009$ & 0 & 0 & 0 & 0 & 0 & $0.0 \mathrm{E}+00$ & $0.0 \mathrm{E}+00$ & $0.0 \mathrm{E}+00$ \\
\hline NY31 & WE & $7 / 15 / 2008$ & 0 & 0.694 & 0 & 9.25 & 0 & $2.5 \mathrm{E}+00$ & $8.1 \mathrm{E}+00$ & $5.3 \mathrm{E}+00$ \\
\hline NY31 & WEQ & $7 / 15 / 2008$ & 0 & 0.725 & 0 & 9.42 & 0 & $2.6 \mathrm{E}+00$ & $8.3 \mathrm{E}+00$ & $5.4 \mathrm{E}+00$ \\
\hline NY31 & WE & $10 / 28 / 2008$ & 0 & 0 & 0 & 0.973 & 0 & $1.9 \mathrm{E}-01$ & $7.8 \mathrm{E}-01$ & 4.9E-01 \\
\hline
\end{tabular}


Table 4. Concentrations of common endocrine-disrupting compounds, hormones, bisphenol A, and estimated estrogenicity for samples collected from wastewater-treatment plant effluents and influents, and receiving streams, in New York, 2008-9.-Continued

[Concentrations are in nanograms per liter (ng/L), except where noted otherwise. na, not determined; Sample medium: WE, effluent; WEQ, replicate; WU, influent; WS, streamwater]

\begin{tabular}{|c|c|c|c|c|c|c|c|c|c|}
\hline \multirow[b]{2}{*}{$\begin{array}{l}\text { Site } \\
\text { code }\end{array}$} & \multirow[b]{2}{*}{$\begin{array}{l}\text { Sample } \\
\text { medium }\end{array}$} & \multirow[b]{2}{*}{$\begin{array}{c}\text { Sample } \\
\text { date }\end{array}$} & \multicolumn{7}{|c|}{ Endocrine-disrupting compounds } \\
\hline & & & 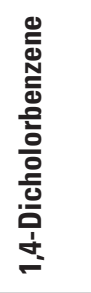 & 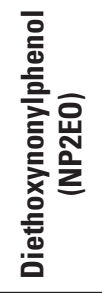 & 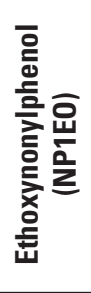 & 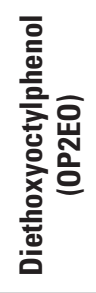 & 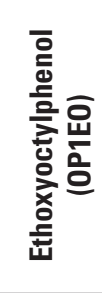 & 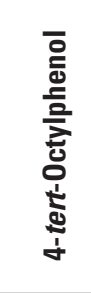 & 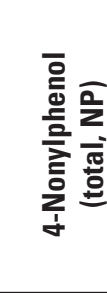 \\
\hline \multicolumn{10}{|c|}{ Effluent samples-Continued } \\
\hline NY31 & WE & $1 / 13 / 2009$ & 0 & 0 & 0 & 0 & 0 & 0 & 0 \\
\hline NY31 & WE & $4 / 27 / 2009$ & 0 & 0 & 0 & 0 & 0 & 0 & 0 \\
\hline NY31 & WEQ & $10 / 19 / 2009$ & 0 & 0 & 0 & 0 & 0 & 0 & 0 \\
\hline NY31 & WE & $10 / 19 / 2009$ & 0 & 0 & 0 & 0 & 0 & 0 & 0 \\
\hline NY32 & WE & $1 / 12 / 2009$ & 0 & 0 & 0 & 0 & 0 & 0 & 0 \\
\hline NY32 & WE & $4 / 27 / 2009$ & 0 & 0 & 0 & 0 & 0 & 0 & 0 \\
\hline NY32 & WE & $10 / 7 / 2009$ & 0 & 0 & 0 & 0 & 0 & 0 & 0 \\
\hline NY33 & WE & $10 / 7 / 2009$ & 0 & 0 & 0 & 0 & 0 & 0 & 0 \\
\hline \multicolumn{10}{|c|}{ Influent samples } \\
\hline NY1 & WU & $10 / 5 / 2009$ & 0.619 & 0 & 0 & 0 & 0 & 0.162 & 2.7 \\
\hline NY2 & WU & $9 / 28 / 2009$ & 0.139 & 5.53 & 0 & 0 & 1.32 & 0.788 & 10.8 \\
\hline NY3 & WU & 10/12/2009 & 0.179 & 4.26 & 0 & 0 & 4.18 & 0.339 & 3.33 \\
\hline NY1 & WS & $10 / 6 / 2009$ & 0 & 0 & 0 & 0 & 0 & 0 & 0 \\
\hline NY2 & WS & $7 / 14 / 2008$ & 0 & 0 & 0 & 0 & 0 & 0 & 0 \\
\hline NY2 & WS & $9 / 30 / 2009$ & 0 & 0 & 0 & 0 & 0 & 0 & 0 \\
\hline NY3 & WS & $7 / 15 / 2008$ & 0 & 0 & 0 & 0 & 0 & 0 & 0 \\
\hline NY3 & WS & $10 / 13 / 2009$ & 0 & 0 & 0 & 0 & 0 & 0 & 0 \\
\hline NY8 & WS & $7 / 15 / 2008$ & 0 & 0 & 0 & 0 & 0 & 0 & 0 \\
\hline NY11 & WS & $9 / 29 / 2009$ & 0 & 0 & 0 & 0 & 0 & 0 & 0 \\
\hline NY23 & WS & $10 / 19 / 2009$ & 0 & 0 & 0 & 0 & 0 & 0 & 0 \\
\hline NY30 & WS & $7 / 15 / 2008$ & 0 & 0 & 0 & 0 & 0 & 0 & 0 \\
\hline NY31 & WS & $7 / 15 / 2008$ & 0 & 0 & 0 & 0 & 0 & 0 & 0 \\
\hline NY31 & WS & $10 / 19 / 2009$ & na & na & na & na & na & na & na \\
\hline NY32 & WS & $7 / 14 / 2008$ & 0 & 0 & 0 & 0 & 0 & 0 & 0 \\
\hline NY32 & WS & $10 / 7 / 2009$ & 0 & 0 & 0 & 0 & 0 & 0 & 0 \\
\hline NY32 & WS & $10 / 7 / 2009$ & 0 & 0 & 0 & 0 & 0 & 0 & 0 \\
\hline
\end{tabular}


Table 4. Concentrations of common endocrine-disrupting compounds, hormones, bisphenol A, and estimated estrogenicity for samples collected from wastewater-treatment plant effluents and influents, and receiving streams, in New York, 2008-9. - Continued

[Concentrations are in nanograms per liter (ng/L), except where noted otherwise. na, not determined; Sample medium: WE, effluent; WEQ, replicate; WU, influent; WS, streamwater]

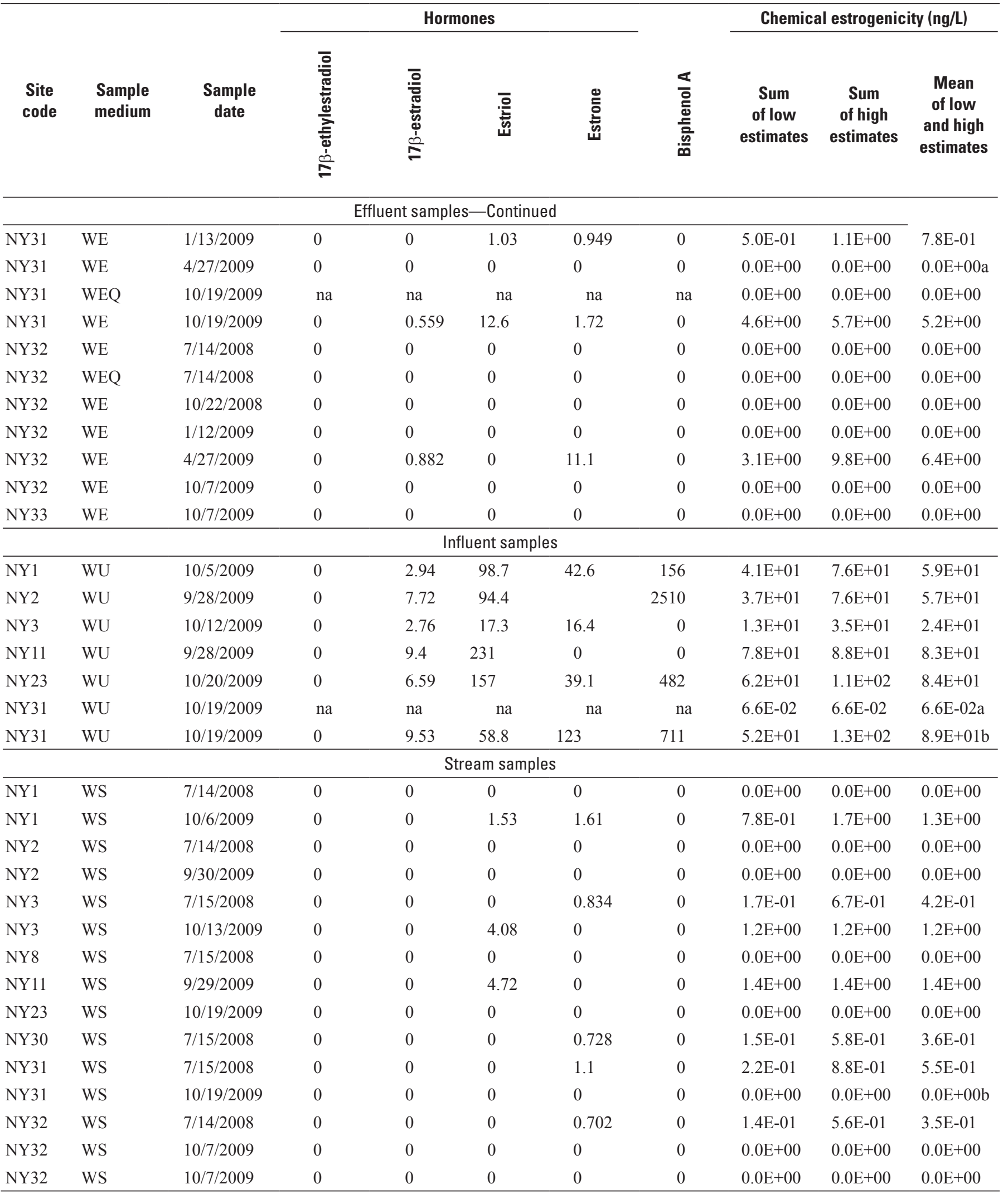




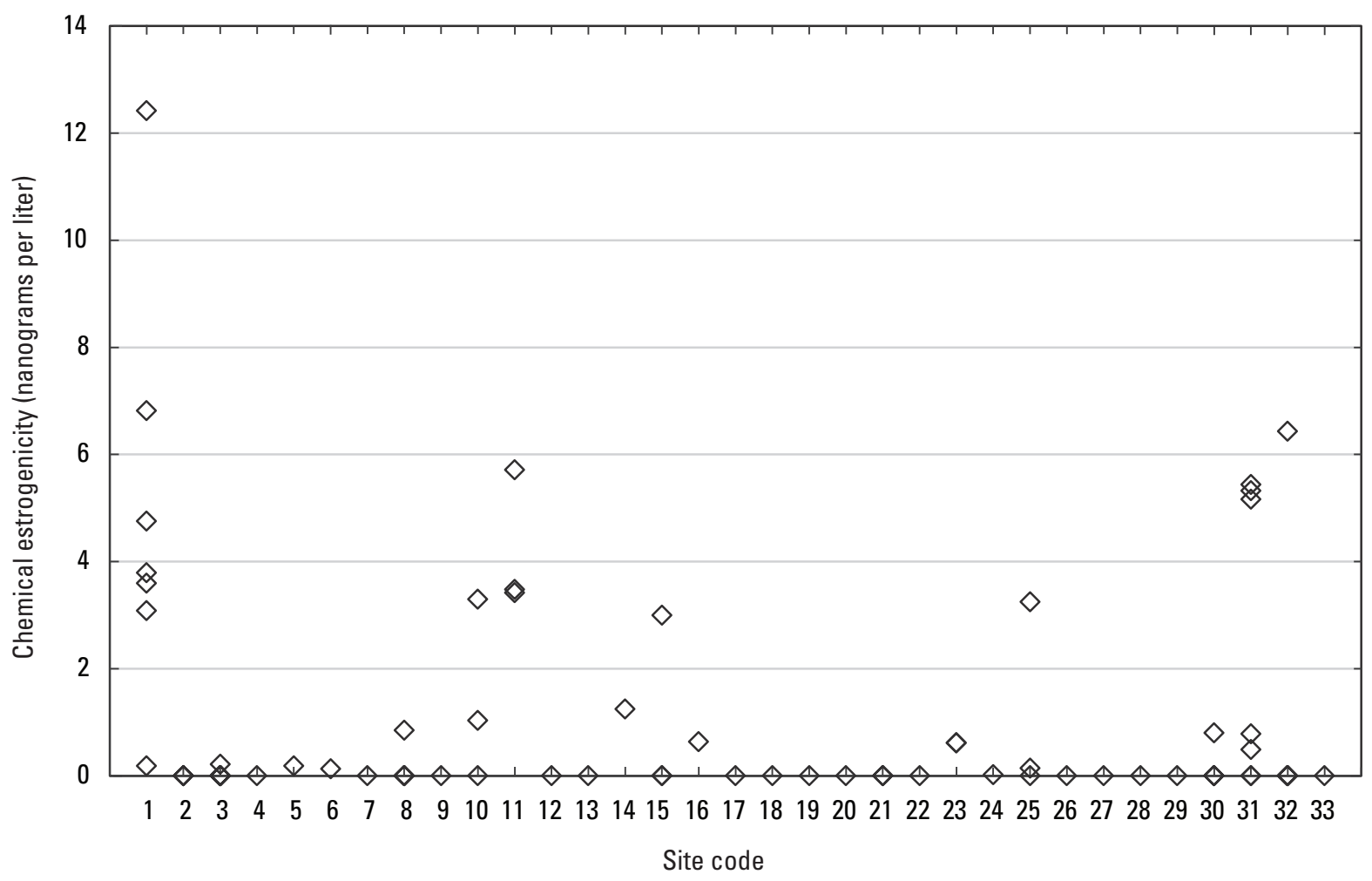

Figure 4. Chemical estrogenicity calculated from all effluent samples collected from 33 wastewater-treatment plants, 2008-9. Sites sampled more than once are denoted by multiple symbols.

mean and median levels of biological estrogenicity (fig. 6A) measured in all WWTP effluents.

The range for chemical estrogenicity data was broader than the range for biological estrogenicity data, yet the order of differences among WWTP types (fig. 6B), with one exception, were comparable to those noted for biological estrogenicity (fig. 6A). The chemical model calculated estrogenicity for most AS-treated effluents was approximately $0 \mathrm{ng} / \mathrm{L}$, whereas e-screen assays estimated estrogenicity was consistently greater than $0.1 \mathrm{ng} / \mathrm{L}$ for the same samples.

\section{Constituent Concentrations}

Concentrations of selected hormones, EDCs, and estimated chemical estrogenicity for samples collected from WWTP effluents, influents, and receiving streams during 2008-9 are summarized in table 4. Measured and estimated concentrations of all PPCPs in influent, effluent, and receiving-stream samples during 2008-9 are summarized in appendix 1. Although most PPCPs were less than the detection limit, a number of PPCPs were estimated at low levels in most streamwater samples. Measurable concentrations of PPCPs were detected in most WWTP effluent and influent samples. The highest levels of PPCPs, however, were identified in WWTP influents. The most commonly detected analytes in all samples were 3,4-dichlorophenyl isocyanate, triethyl citrate, tris(2-chloroethyl)phosphate (TCEP), caffeine, tris(dichloroisopropyl)phosphate (TCPP), and benzophenone (appendix 1). The analytes TCEP, TCPP, and benzophenone are suspected of being EDCs (Kim and others, 2007). Other known or suspected EDCs detected in samples are 1,3,4,6,7,8-hexahydro-4,6,6,7,8,8-hexamethylcyclopenta$\gamma$-2-benzopyran (HHCB), triclosan, acetyl hexametyl tetrahydronaphthalene (AHTN), 1,4-dicholobenzene, bisphenol A (BPA), 3-methyl-1(H)-indole, and some form of nonylphenol (appendix 1). The number of PPCPs detected in each WWRP effluent sample ranged from 0 to 14 with an average of 7.3 (out of a total of 69). The number of PPCPs detected in each streamwater sample ranged from 7 to 25 with an average of 12.1, and the number of PPCPs in each influent sample ranged from 7 to 14 with an average of 11.2.

Measured hormone concentrations in WWTP influent, effluent, and receiving stream samples are summarized in 


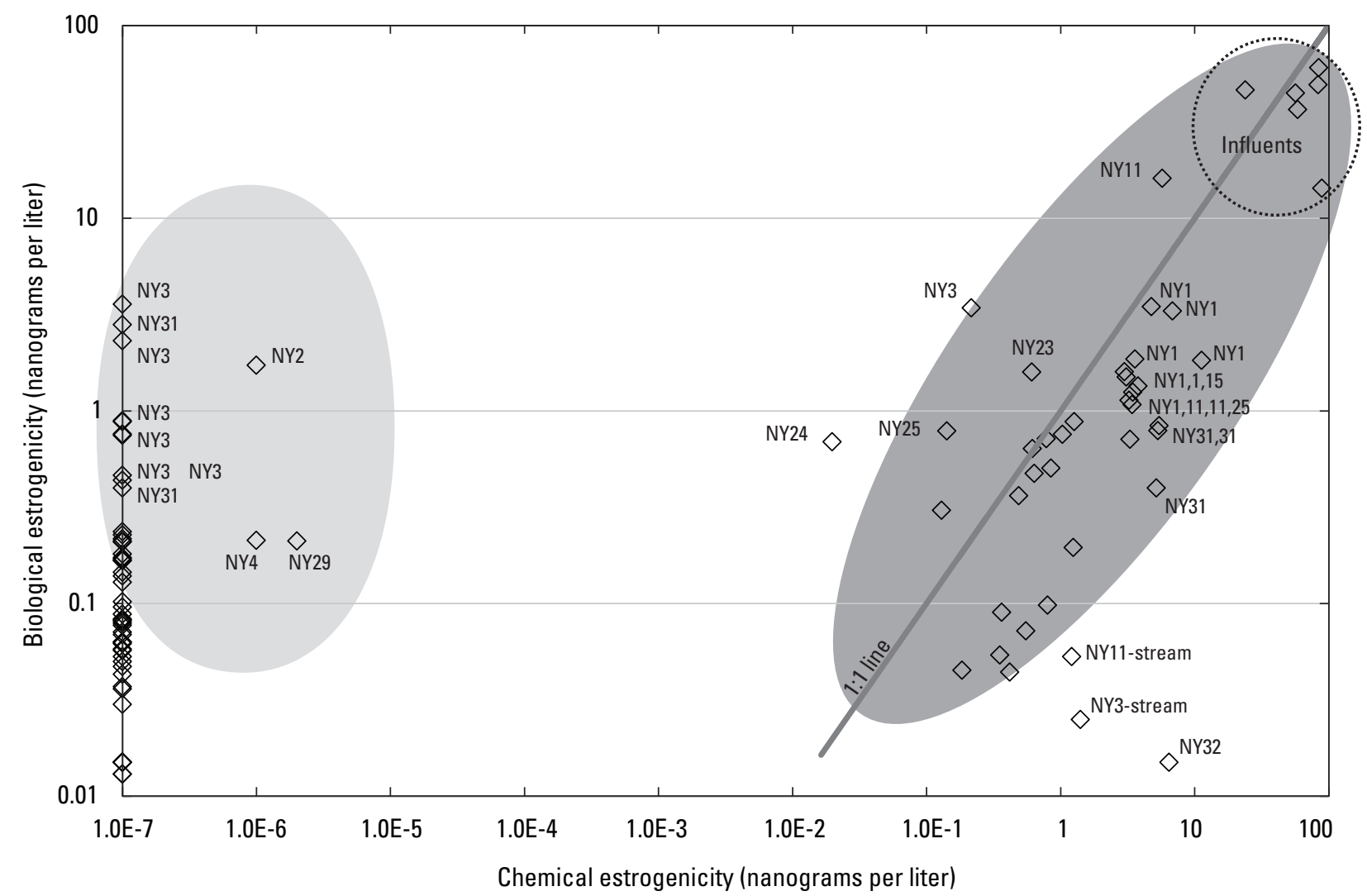

Figure 5. Measured biological estrogenicity in relation to estimated chemical estrogenicity for all effluent and influent samples collected at 33 wastewater-treatment plants in New York, 2008-9. The solid line represents the one-to-one relation between the two values of estrogenicity. Circled points show results for influent samples. The estrogenicity for sample points in the lighter shaded region (to the left) arises mainly from non-hormone endocrine-disrupting compounds, whereas the estrogenicity for sample points in the darker shaded region (to the right) arises mainly from hormones.

appendix 2. The most notable hormones detected in effluent and streamwater samples were 4-androstene-3,17-dione, estrone, cis-androsterone, 17ß-estradiol, and estriol. The number of hormones detected in each WWTP effluent sample ranged from 0 to 10 with an average of 2.1 (out of a total of 20). The number of hormones detected in each streamwater sample ranged from 0 to 13 with an average of 1.7 , and the number of hormones detected in each influent sample ranged from 0 to 13 with an average of 9.2.

The total suspended solid (TSS) concentrations measured in effluent and receiving stream samples are provided in table 5. More than one-half (36) of the 53 treated effluent samples had TSS concentrations that were less than the detection limit (1 milligram per liter $(\mathrm{mg} / \mathrm{L})$ ). Concentrations of TSS in the other 17 samples ranged from 1 to $109 \mathrm{mg} / \mathrm{L}$ with a median of $8 \mathrm{mg} / \mathrm{L}$. The sites with the highest TSS levels were NY13 (109 mg/L), NY30 (12.5 to $58 \mathrm{mg} / \mathrm{L}$ ), and NY31 (4 to $33.5 \mathrm{mg} / \mathrm{L}$ ). Except for NY1 (where TSS was less than $1.0 \mathrm{mg} / \mathrm{L}$ ), concentrations of TSS in receiving streams ranged from 1.5 to $18.5 \mathrm{mg} / \mathrm{L}$.

\section{Spatiotemporal Variations in Estrogen, Other Hormones, and Endocrine- Disrupting Compounds}

Five central conclusions may be drawn from findings of the study. First, estrogenicity varies spatially and seasonally within effluents from WWTPs. This is not a novel finding, as prior investigations have determined that the levels of estrogenic steroids and (or) estrogenicity of effluents can vary seasonally and even daily (Hemming and others, 2004; Fernandez and others, 2008; Avbersek and others, 2011). Second, a wide range of known and unknown EDCs are present in both WWTP effluents and the streams that receive effluents. Third, WWTP effluents may be important sources of estrogenicity in weakly diluted streams. Fourth, measures of biological estrogenicity are often much higher than estimates of chemical estrogenicity, especially where effluents have few or low levels of hormones. This is important because 


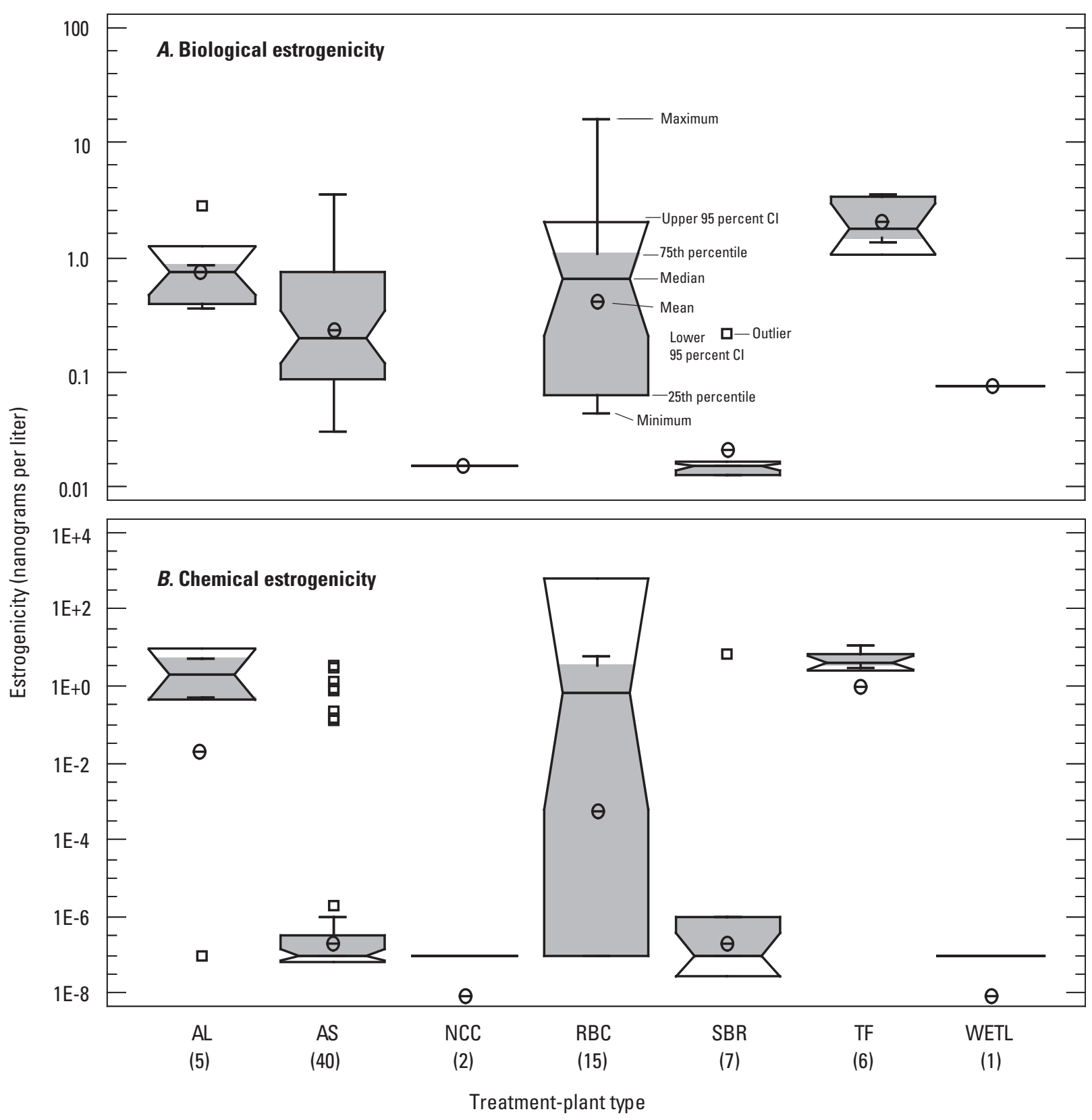

Figure 6. Box plots of $A$, biological and $B$, chemical estrogenicity of treated wastewater effluents from seven different treatment processes. (AS, activated sludge; $R B C$, rotating biological contactor; $S B R$, sequential batch reactor; $A L$, aerated lagoon; TF, trickling filter; NCC, non-contact cooling; WETL, wetland-landfill; CI, confidence interval) 
Table 5. Concentrations of total suspended solids in samples of wastewater-treatment-plant effluents and receiving streams, New York, 2008-9.

[TSS, total suspended solids; mg/L, milligrams per liter; ID, identifier; <, less than]

\begin{tabular}{|c|c|c|c|c|}
\hline Site code & Station ID & Sample date & $\begin{array}{c}\text { Time } \\
\text { (24-hour) }\end{array}$ & $\begin{array}{c}\text { TSS } \\
\text { (mg/L) }\end{array}$ \\
\hline \multicolumn{5}{|c|}{ Treated effluents } \\
\hline NY2 & 412450073400901 & $7 / 14 / 2008$ & 1000 & $<1$ \\
\hline NY3 & 422212074405501 & $7 / 15 / 2008$ & 1000 & $<1$ \\
\hline NY31 & 423618075312001 & $7 / 15 / 2008$ & 1210 & 20 \\
\hline NY30 & 423314075312701 & $7 / 15 / 2008$ & 930 & 12.5 \\
\hline NY8 & 420936075081801 & $7 / 15 / 2008$ & 1400 & $<1$ \\
\hline NY32 & 445337073281301 & $7 / 14 / 2008$ & 1030 & 5.5 \\
\hline NY1 & 411700073452001 & $7 / 14 / 2008$ & 1300 & 1 \\
\hline NY4 & 421054074473001 & $10 / 21 / 2008$ & 900 & $<1$ \\
\hline NY5 & 412433073363901 & $10 / 22 / 2008$ & 930 & $<1$ \\
\hline NY6 & 421319075181801 & $10 / 20 / 2008$ & 920 & $<1$ \\
\hline NY11 & 412332073370901 & $10 / 28 / 2008$ & 1010 & 1.5 \\
\hline NY7 & 412411073372001 & $10 / 28 / 2008$ & 940 & $<1$ \\
\hline NY2 & 412450073400901 & $10 / 22 / 2008$ & 1100 & $<1$ \\
\hline NY9 & 412118073441801 & $10 / 29 / 2008$ & 1150 & $<1$ \\
\hline NY10 & 412301073473301 & $10 / 29 / 2008$ & 1120 & $<1$ \\
\hline NY12 & 421519074562701 & $10 / 20 / 2008$ & 1230 & $<1$ \\
\hline NY13 & 421433074573701 & $10 / 20 / 2008$ & 1130 & 109 \\
\hline NY14 & 420923074323801 & $10 / 22 / 2008$ & 930 & $<1$ \\
\hline NY15 & 413034073362801 & $10 / 28 / 2008$ & 850 & $<1$ \\
\hline NY16 & 422141074282601 & $10 / 21 / 2008$ & 1100 & $<1$ \\
\hline NY17 & 415038074322601 & $10 / 22 / 2008$ & 1100 & $<1$ \\
\hline NY18 & 421206074100801 & $10 / 27 / 2008$ & 940 & $<1$ \\
\hline NY3 & 422212074405501 & $10 / 20 / 2008$ & 1130 & $<1$ \\
\hline NY19 & 421259074142701 & $10 / 27 / 2008$ & 830 & $<1$ \\
\hline NY20 & 421012075081601 & $10 / 20 / 2008$ & 1030 & 6.5 \\
\hline NY21 & 412245073432601 & $10 / 29 / 2008$ & 1100 & $<1$ \\
\hline NY22 & 421443074574901 & $10 / 20 / 2008$ & 1205 & $<1$ \\
\hline NY23 & 420821074391601 & $10 / 21 / 2008$ & 1010 & $<1$ \\
\hline NY31 & 423618075312001 & $10 / 28 / 2008$ & 940 & 23 \\
\hline NY30 & 423314075312701 & $10 / 28 / 2008$ & 900 & 21.5 \\
\hline NY24 & 420721074274901 & $10 / 22 / 2008$ & 900 & $<1$ \\
\hline NY25 & 421908074261101 & $10 / 21 / 2008$ & 1200 & $<1$ \\
\hline NY26 & 422410074374001 & $10 / 21 / 2008$ & 800 & $<1$ \\
\hline NY27 & 421113074090301 & $10 / 27 / 2008$ & 910 & $<1$ \\
\hline NY8 & 420936075081801 & $10 / 21 / 2008$ & 1200 & $<1$ \\
\hline NY28 & 411812073394501 & $10 / 29 / 2008$ & 850 & $<1$ \\
\hline NY29 & 421811074165101 & $10 / 27 / 2008$ & 740 & $<1$ \\
\hline NY32 & 445337073281301 & $10 / 22 / 2008$ & 940 & $<1$ \\
\hline NY1 & 411700073452001 & $10 / 22 / 2008$ & 1300 & $<1$ \\
\hline NY2 & 412450073400901 & $1 / 12 / 2009$ & 1300 & 1 \\
\hline NY3 & 422212074405501 & $1 / 13 / 2009$ & 0930 & $<1$ \\
\hline
\end{tabular}


Table 5. Concentrations of total suspended solids in samples of wastewater-treatment-plant effluents and receiving streams, New York, 2008-9.-Continued

[TSS, total suspended solids; mg/L, milligrams per liter; ID, identifier; <, less than]

\begin{tabular}{|c|c|c|c|c|}
\hline Site code & Station ID & Sample date & $\begin{array}{c}\text { Time } \\
\text { (24-hour) }\end{array}$ & $\begin{array}{c}\text { TSS } \\
\text { (mg/L) }\end{array}$ \\
\hline \multicolumn{5}{|c|}{ Treated effluents } \\
\hline NY31 & 423618075312001 & $1 / 13 / 2009$ & 1020 & 4 \\
\hline NY30 & 423314075312701 & $1 / 13 / 2009$ & 0920 & 15 \\
\hline NY8 & 420936075081801 & $1 / 14 / 2009$ & 1000 & $<1$ \\
\hline NY32 & 445337073281301 & $1 / 12 / 2009$ & 1100 & 3 \\
\hline NY1 & 411700073452001 & $1 / 14 / 2009$ & 1330 & $<1$ \\
\hline NY2 & 412450073400901 & $4 / 28 / 2009$ & 0700 & $<1$ \\
\hline NY3 & 422212074405501 & $4 / 27 / 2009$ & 1230 & $<1$ \\
\hline NY31 & 423618075312001 & $4 / 27 / 2009$ & 1000 & 33.5 \\
\hline NY30 & 423314075312701 & $4 / 27 / 2009$ & 0900 & 58 \\
\hline NY8 & 420936075081801 & $4 / 28 / 2009$ & 1430 & $<1$ \\
\hline NY32 & 445337073281301 & $4 / 27 / 2009$ & 1030 & 8 \\
\hline NY1 & 411700073452001 & $4 / 28 / 2009$ & 1200 & 1 \\
\hline \multicolumn{5}{|c|}{ Receiving streams } \\
\hline NY2 & 01374674 & $7 / 14 / 2008$ & 1145 & 11 \\
\hline NY3 & 01421640 & $7 / 15 / 2008$ & 1100 & 1.5 \\
\hline NY31 & 01505021 & $7 / 14 / 2008$ & 1315 & 10 \\
\hline NY30 & 01505023 & $7 / 15 / 2008$ & 1100 & 18.5 \\
\hline NY8 & 01423010 & $7 / 15 / 2008$ & 1430 & 6.5 \\
\hline NY32 & 04271555 & $7 / 14 / 2008$ & 1400 & 6.5 \\
\hline NY1 & 01374963 & $7 / 14 / 2008$ & 1430 & $<1$ \\
\hline
\end{tabular}

comparisons of estrogenicity determined using different methods provides insight into the specific pharmaceuticals or wastewater compounds that may be causing effluents to be estrogenic. Lastly, the type of treatment appears to have a large effect on the ability of WWTPs to remove EDCs from effluents that are discharged into receiving streams. Interrelated information on treatment processes, EDCs, and estrogenicity of wastewater effluents and receiving streams can only improve our understanding of (1) the compounds that potentially affect endocrine systems of aquatic organisms, (2) the effectiveness of regulatory standards, and (3) the efficacy of various treatment processes to sustain water quality and biologic communities in streams across New York.

The EDCs that make many WWTP effluents estrogenic are of concern because of the potential adverse effects that these compounds could have on the reproductive systems of resident fish and other aquatic biota. The recent discovery that numerous non-hormones, including PPCPs, found in wastewaters can cause serious estrogenic effects has created a new awareness of these emerging contaminants. One attempt to characterize the potential estrogenicity of effluents is use of the chemical estrogenicity model which incorporates both hormones and estrogenic EDCs. The estrogenic effect and the weight applied to non-hormone EDCs, however, is often orders of magnitude lower than that of most hormones used in the chemical-based model (Vajda and others, 2008). Hormones can induce feminization within the tissues of fish and other organisms at very low (less than $1.0 \mathrm{ng} / \mathrm{L}$ ) concentrations (Routledge and others, 1998), whereas non-hormone EDCs can be as much as 1,000 times as potent. Many non-hormone EDCs and their degradates, however, are ubiquitous chemicals that occur 1,000 or more times as frequently as hormones in surface waters, so their total contribution to estrogenicity may be just as important, if not more important, to resident biota, than that of natural and synthetic hormones.

Results from the present study show that e-screen measures of biological estrogenicity were often several orders of magnitude greater than modeled levels of chemical estrogenicity, especially at several study sites. The opposite was also true for a small number of samples, but differences were generally less than an order of magnitude (fig. 5). There were, however, greater discrepancies between measures of biological and chemical estrogenicity in samples from some WWTPs than from others. The samples with hormone detections had relatively strong 1:1 relations between chemical and biological estrogenicity, whereas the samples without 
hormone detections had weak or poor associations. Therefore, other hormones and (or) non-hormone EDCs which are not listed in table 2 must be contributing to the total estrogenicity in this group of effluent samples, and the chemical estimates appear to underpredict total effluent estrogenicity. The disagreement between biological and chemical estrogenicity data is most obvious for activated-sludge WWTP effluents (fig. 6B). Alternatively, compounds within the effluents may be acting synergistically to create conditions whereby total estrogen activity (quantified by measures of biological estrogenicity) is unusually high. In either situation, the biological values would be the least conservative means to characterize total estrogenicity of WWTP effluents and the more responsive metric at most of the treatment plants. For example, sites NY3 and NY31 had some of the highest e-screen assay results with samples from both sites usually exceeding the $1.0 \mathrm{ng} / \mathrm{L} \mathrm{E} 2 \mathrm{Eq}$; yet, all but a few calculations of chemical estrogenicity predicted low to no estrogenic activity.

There are several reasons for the observed discrepancies between chemical and biological measures of estrogenicity. First, the model used in this study for chemical estrogenicity weighted the estrogenic effect of hormones 4 to 5 orders of magnitude higher than that of EDCs, based on compoundspecific studies showing relatively low potencies for nonhormone EDCs. Though the estrogenic effects of many hormones and some mimics have been quantified, the large differences in many estimates using the two methods suggest that the chemical model is incomplete and the estrogenic effects of many non-hormone EDCs are unknown. Second, the model used in this study did not include all the known and suspected EDCs found in our samples, and some of those compounds may have contributed to a higher level of biological estrogenicity than was estimated using the chemical EDCs alone. Third, there may be one or more compounds present in the study samples that have not been identified as an EDC and that contribute to measures of biological estrogenicity, but not to chemical estrogenicity. Fourth, the chemical estrogenicity (model) estimates are based primarily on dissolved compounds which pass through a filter and cannot account for estrogenicity that may be bound to suspended sediments (solids). Thus, the whole-water sample used for e-screen assays (and measured biological estrogenicity) could be quantifying the total estrogenicity, whereas the chemical methods could be missing some of the estrogenicity that is associated with the solids. This is conceivable considering the facts that (1) Furlong and others (2010) found the relations between biological and chemical estrogenicity were stronger for solid matrices than for liquid samples, (2) the extraction efficiencies for the e-screen assays can vary for different estrogenic compounds, and (3) some of these compounds may sorb to solids and be less bioavailable to the cells used in the e-screen assays. Lastly, the additive estrogenicity of compounds used in the chemical models may not accurately depict the total estrogenicity because synergistic and (or) antagonistic interactions may occur within the complex mixtures of hormones and non-hormone EDCs found in WWTP effluents. The chemical estrogenicity models rely on weights derived from highly controlled exposures to individual hormones and EDCs. Thus, the chemical estrogenicity of complex mixtures of EDCs in effluents might be expected to differ from a simple addition of their weighted concentrations (Thorpe and others, 2003; Bertanza and others, 2011). In fact, the results from several studies showed that mixtures of EDCs can sometimes have a synergistic effect on biological or total estrogenicity. Silva and others (2002), for example, found that eight weak estrogenic chemicals with concentrations less than the level of observable effects combined to produce significant mixture effects, and Rajapakse and others (2002) found that mixtures of several low-potency EDCs increased the effect of the estrogen 17 $\beta$-estradiol, even when the EDCs were all less than levels of observable effect. Estimation of total estrogenicity using chemical models will remain problematic until more is known about the effects and interactions of a large variety of EDCs.

The fact that chemical estrogenicity often underpredicted the e-screen measures of biological estrogenicity was surprising considering several studies found the opposite relation. For example, Furlong and others (2010) developed a model of chemical estrogenicity similar to the model used in this study and based on four WWTPs across the United States. Compounds were weighted by their $17 \alpha$-ethinyl-estradiol (EE2) equivalents rather than $17 \beta$-estradiol equivalents (E2 Eq) used in the model by Vajda and others (2008), and several different EDCs were included. In addition to chemical estrogenicity, Furlong and others (2010) measured biological estrogenicity using an e-screen assay and another bioassay measuring the response of breast cancer cells to water samples (the T47D-KBluc reporter gene bioassay). They found that both measures of biological estrogenicity were lower than the chemical estrogenicity in their samples and stated that this finding was not unusual because chemical estrogenicity does not include any biological processes, such as competitive binding by different compounds for the estrogen receptor sites, the role of estrogenic antagonists in the wastewater matrix, or diminished transport of agonists due to wastewater matrix effects (Furlong and others, 2010). Likewise, Rajapakse and others (2004) concluded that the presence of 4-nonylphenol and 4-tert-octylphenol caused antagonism, which resulted in measures of biological estrogenicity that were lower than the chemical estrogenicity estimated using their model.

Regardless of whether the model for chemical estrogenicity over-predicts or under-predicts the biological estrogenicity of a sample, the e-screen bioassay results indicate that moderate to high levels of estrogenicity are unexplained by the chemical estrogenicity model. For example, sites NY3 and NY31 have high levels of biological estrogenicity and low levels of chemical estrogenicity. Both of these sites treat influents which include pharmaceutical plants in their inflow stream. One possible inference is that some of the compounds released by these plants are highly estrogenic and that they contribute to overall estrogenicity of the WWTP effluent. Whether these compounds are known to be EDCs 
or not, they have not been incorporated into the chemical estrogenicity model used in this study and yield much higher levels of biological estrogenicity than would be expected solely from the measured concentrations of hormone and nonhormone EDCs.

The type of treatment (process) at the different WWTPs appeared to have a notable effect on the estrogenicity of the effluents. Measures of chemical and biological estrogenicity were moderately high in effluents from aerated lagoons (AL) and trickling filters (TF), whereas they were relatively low and often below detection limits in effluents from plants using activated sludge (AS) and sequential batch reactors (SBR). Although samples of effluents were collected from only one $\mathrm{AL}$ and one TF plant, estrogenicity of most samples from those sites were generally higher than in effluent samples from other types of plants. In fact, the average removal efficacy for the six treatment types could account for 78 and 95 percent of the variability in mean and median levels of biological estrogenicity, respectively, (fig. 6A) measured in effluents from all the WWTPs sampled for this study. The results from Kasprzyk-Hordern and others (2008) largely confirm the low estrogenicity-removal efficacy for the TF process but a relatively high removal efficacy for the AS treatment process. These investigators found that the TF treatment process removed less than 70 percent of the 55 PPCPs, and the AS process removed more than 85 percent of the PPCPs in effluents from two WWTPs in South Wales, United Kingdom. In a review of several studies, Johnson and Sumpter (2001) concluded that AS plants were very effective and consistently removed more than 85 percent of estrogenic hormones (estradiol, estriol, and ethinylestradiol) from the waste stream. One study (Baronti and others, 2000) observed that the AS process removed, on average, 61 percent of estrone (E1), 87 percent of $17 \beta$-estradiol (E2), 95 percent of estriol (E3), and 85 percent of ethinyl estradiol (EE2) from samples from six WWTPs in Italy. Joss and others (2004) also found that the AS process in a Swiss WWTP removed more than 90 percent of all estrogens from the influent. Thus, it is not surprising that AS plants are generally recognized as one of the most effective removers of estrogenicity in municipal wastewaters.

Removal effectiveness cannot always be characterized simply by comparing influent and effluent concentrations of compounds at WWTPs. When a compound is removed from the liquid phase, it is no longer detected, but it is impossible to tell whether it was chemically transformed to another compound (that is, no longer present in any form) or sorbed onto solids (that is, physically removed from the liquid, but still present). Furlong and others (2010) found that estrogens were removed from the liquid phase largely through chemical transformation to other compounds; 99 percent of estriol (E3), 92 percent of estradiol (E2), and 61 percent of estrone (E1) were transformed. However, E1 is a metabolite of E2, and E2 is a metabolite of $\mathrm{E} 3$, so these final figures cannot quantify or determine how much E3 and (or) E2 was transformed into E1. Estrogens have an aromatic ring that makes them less susceptible to biological processes like aerobic digestion.
Furlong and others (2010) found that androgens were typically more abundant in WWTP influents in their study than were estrogens, but more than 95 percent were removed by treatment processes. Andersen and others (2003) found that only 5 percent of estrogens (E1, E2, and EE2) were sorbed onto sludge at a municipal WWTP in Germany, and Johnson and Sumpter (2001) indicate that EE2 may have the highest sorption rate because it is more hydrophobic than E1 and E2.

Only a fraction of the many organic compounds released into the environment were measured in this study, and without the technology to analyze for these compounds, nor improved information on whether a compound acts as an endocrine disrupter, the full extent of occurrence of EDCs in effluents and receiving streams cannot be completely ascertained. Results from this study, however, indicate that at least some hormones and non-hormone EDCs persist in most effluents following treatment. Concentrations of hormones and hormone-mimicking compounds from WWTP effluents vary seasonally within individual WWTPs and broadly among WWTPs, and that biologically relevant concentrations of some EDCs likely occur in receiving streams within the area studied and in other streams throughout New York State.

\section{Summary}

In 2008, the U.S. Geological Survey (USGS), New York State Department of Environmental Conservation, New York State Department of Health, and New York City Department of Environmental Protection began an investigation to improve the understanding of estrogenicity and endocrine-disrupting compounds (EDCs) in wastewater effluents and receiving streams, mainly in southeastern New York. The primary goals of this study were to document and assess the (a) spatial and temporal variability of estrogenicity; (b) effectiveness of various treatment-plant types to remove estrogenicity; (c) concentrations of hormones, EDCs, and pharmaceuticals and personal care products (PPCPs); and (d) the relations between estrogenicity and concentrations of hormones, EDCs, and PPCPs. The potential effects of EDCs on the water quality and health of biota in streams of the New York City Water Supply are a concern because more than 150 wastewatertreatment plants (WWTPs) are permitted to discharge effluents into surface waters and groundwaters of watersheds that provide potable water to more than 9 million people.

Estrogenicity and levels of selected hormones, nonhormone EDCs, and PPCPs were characterized in water samples collected (1) seasonally (4 times) from effluents at 7 municipal and pharmaceutical WWTPs, (2) 1 to 2 times from WWTP receiving streams, (3) 1 to 2 times at 26 additional WWTPs in both NYC watersheds, and (4) 1 time from influents to 6 WWTPs. The effluent, stream, and influent sites were chosen to represent a range of different waste-water treatment types. Data from all the sites and surveys were used to assess spatiotemporal patterns and important inter-relations 
among target constituents. Estrogenicity was quantified, as estradiol equivalents, using biological (e-screen) assays and a chemical model.

Key findings generally demonstrate that (1) estrogenicity in effluents varied spatially and seasonally, (2) a wide range of known and unknown EDCs were present in WWTP effluents and receiving streams, (3) some effluents could be important sources of estrogenicity in weakly diluted streams, (4) measured levels of biological estrogenicity were often higher than estimated levels of chemical estrogenicity, and (5) the type of treatment had a large effect on the removal efficiency and consequently the estrogenicity levels observed in the final effluents. Biological estrogenicity in WWTP influents, effluents, and receiving streams varied widely among sites and sampling periods or seasons. The biological estrogenicity of WWTP influents was generally very high (14.3 to 60.3 nanograms per liter (ng/L), whereas estradiol equivalent $(\mathrm{E} 2 \mathrm{Eq})$ levels in receiving streams were usually below the detection limit or low $(0.025$ to $0.879 \mathrm{ng} / \mathrm{L})$.

Biological estrogenicity in effluents ranged from less than the detection limit (typically $0.027 \mathrm{ng} / \mathrm{L}$ ) to a high of $16.08 \mathrm{ng} / \mathrm{L}$. Though the estrogenicity of many effluent samples was relatively low, the estrogenicity at two sites with numerous samples (NY1 and NY11) was always high ( > $1.0 \mathrm{ng} / \mathrm{L}$ ), and more than one-half of all samples were at least marginally estrogenic $(>0.1 \mathrm{ng} / \mathrm{L})$. Seasonal variations in biological estrogenicity were comparable among effluents from most of the seven WWTPs. Although the magnitude of E2 Eq concentrations differed among sites, the sequence of E2 Eq levels (from low to high) was relatively consistent, and except for NY1, concentrations were highest during spring and lower during fall and summer. The E2 Eq concentrations for all sites (except NY31 in January) sampled before and after the April 2009 survey were consistently less than $1.0 \mathrm{ng} / \mathrm{L}$. The estimates of chemical estrogenicity (mean values calculated from low and high estimates for measured hormones and non-hormone EDCs) in WWTP influents, effluents, and receiving streams, also varied widely among sites and seasons. The chemical estrogenicity levels ranged from 24.8 to $88.6 \mathrm{ng} / \mathrm{L} \mathrm{E} 2 \mathrm{Eq}$ for WWTP influents, were consistently less than $1.30 \mathrm{ng} / \mathrm{L}$ for all stream samples, and ranged from 0 to $12.42 \mathrm{ng} / \mathrm{L}$ E2 Eq for all effluent samples. Mean levels of chemical estrogenicity were sometimes much lower than the mean measures of biological (e-screen) estrogenicity within split samples, which indicates that the estrogenicity in several effluents may be affected by additional, and possibly unknown, EDCs or that the use of the average low and high predictions to quantify chemical estrogenicity is not valid.

The type of WWTP process appears to have a large effect on the efficiency of removal of estrogenic compounds and, thus, on the estrogenicity levels that were measured in the effluents of six WWTPs. Effluents samples from plants using either an aerated lagoon (AL) or trickling filter (TF) had higher levels of biological estrogenicity than other types, whereas estrogenicity was lowest in effluents from sequential batch reactors (SER). Estimated removal efficiencies for biological estrogenicity averaged 95.3 percent at one TF plant, 97.2 percent at one AL plant, 97.5 percent at two rotating biological contactor (RBC) plants, 99.3 percent at two activated sludge (AS) plants, and 97.7 percent (overall) at all six plants. Although the range in efficiencies among the four plant types was small, the mean removal efficiency (for the four treatment types) could account for 78 and 95 percent of the variability in mean and median levels of biological estrogenicity measured in effluents from these six WWTPs. Although most measured and estimated concentrations of PPCPs were below the detection limit, a number of PPCPs were found at low levels in most streamwater samples and at higher levels in most WWTP effluent and influent samples. On average, 7.3 PPCPs (out of a total of 69) were detected in each effluent sample; an average of 12.1 PPCPs were detected in each streamwater sample, and an average of 11.2 PPCPs were detected in each influent sample. The most commonly detected analytes were 3,4-dichlorophenyl isocyanate, triethyl citrate, tris(2-chloroethyl)phosphate (TCEP), caffeine, tri(dichloroisopropyl)phosphate (TCPP), and benzophenone. Numerous anlaytes (TCEP, TCPP, benzophenone, 1,3,4,6,7,8-hexahydro-4,6,6,7,8,8-hexamethylcyclopentay-2-benzopyran (HHCB), triclosan, acetyl hexamethyl tetrahydronaphthalene (AHTN), 1,4-dicholobenzene, bisphenol A (BPA), 3-methyl-1(H)-indole, and some form of nonylphenol) are known or suspected to be EDCs.

Most results indicate that WWTP effluents are relatively minor sources of biological and chemical estrogenicity in receiving streams. Biologically meaningful levels of estrogenicity, however, are plausible in weakly diluted streams, that is, small streams that have large WWTPs and effluents characterized by high estrogenicity. Although such situations appear to be uncommon, they could conceivably affect the health of individual organisms, their populations, and entire communities of aquatic biota in streams across New York State. 


\section{References Cited}

Andersen, H., Siegrist, H., Halling-Sørensen, B., and Ternes, T.A., 2003, Fate of estrogens in a municipal sewage treatment plant: Environmental Science \& Technology, v. 37 , no. 18 , p. $4021-4026$.

Avbersek, M., Somen, J., and Heath, E., 2011, Dynamics of steroid estrogen daily concentrations in hospital effluent and connected waste water treatment plant: Journal of Environmental Monitoring, v. 13, no. 8, p. 2221-2226.

Baldigo, B.P., Sloan, R.J., Smith, S.B., Denslow, N.D., Blazer, V.S., and Gross, T.S., 2006, Polychlorinated biphenyls, mercury, and potential endocrine disruption in fish from the Hudson River, New York, USA: Aquatic Sciences, v. 68, no. 2, p. 206-228.

Baronti, Chiara, Curini, Roberta, D’Ascenzo, Giuseppe, Di Corcia, Antonio, Gentili, Alessandra, and Samperi, Roberto, 2000, Monitoring natural and synthetic estrogens at activated sludge sewage treatment plants and in a receiving river water: Environmental Science \& Technology, v. 34, no. 24, p. 5059-5066.

Beek, I.C., Bruhn, R., and Gandrass, J., 2006, Analysis of estrogenic activity in coastal surface waters of the Baltic Sea using the yeast estrogen screen: Chemosphere, v. 63, no. 11 , p. 1870-1878.

Bertanza, G., Pedrazzani, R., Dal Grande, M., Papa, M., Zambarda, V., Montani, C., Steimberg, N., Mazzoleni, G., and Di Lorenzo, D., 2011, Effect of biological and chemical oxidation on the removal of estrogenic compounds (NP and BPA) from wastewater: An integrated assessment procedure: Water Research, v. 45, no. 8, p. 2473-2484.

Blazer, V.S., Iwanowicz, L.R., Iwanowicz, D.D., Smith, D.R., Young, J.A., Hedrick, J.D., Foster, S.W., and Reeser, S.J., 2007, Intersex (testicular oocytes) in smallmouth bass from the Potomac River and selected nearby drainages: Journal of Aquatic Animal Health, v. 19, no. 4.

Cahill, J.D., Furlong, E.T., Burkhardt, M.R., Kolpin, D., and Anderson, L.G., 2004, Determination of pharmaceutical compounds in surface- and ground-water samples by solid-phase extraction and high-performance liquid chromatography-electrospray ionization mass spectrometry: Journal of Chromatography A, v. 1041, no. 1-2, p. 171-180.

Cao, Q.M., Yu, Q.M., and Connell, D.W., 2010, Fate simulation and risk assessment of endocrine disrupting chemicals in a reservoir receiving recycled wastewater: Science of the Total Environment, v. 408, no. 24, p. $6243-6250$.
Carlson, A.R., Brungs, W.A., Chapman, G.A., and Hansen, D.J., 1984, Guidelines for deriving numerical aquatic sitespecific water quality criteria by modifying national criteria: USEPA/Environmental Research Lab EPA-600/S3-84-099.

Castiglioni, S., Bagnati, R., Fanelli, R., Pomati, F., Calamari, D., and Zuccato, E., 2006, Removal of pharmaceuticals in sewage treatment plants in Italy: Environmental Science \& Technology, v. 40, p. 357-363.

Cheek, A.O., 2006, Subtle sabotage: endocrine disruption in wild populations: Revista de Biologia Tropical, v. 54, p. 1-19.

Clara, M., Strenn, B., Gans, O., Martinez, E., Kreuzinger, N., and Kroiss, H., 2005, Removal of selected pharmaceuticals, fragrances and endocrine disrupting compounds in a membrane bioreactor and conventional wastewater treatment plants: Water Research, v. 39, no. 19, p. 4797-4807.

Drewes, J.E., Hemming, J., Ladenburger, S.J., Schauer, J., and Sonzogni, W., 2005, An assesment of endocrine disrupting activity changes during wastewater treatment through the use of bioassays and chemical measurements: Water Environment Research, v. 77, no. 1, p. 12-23.

Fernandez, M.P., Buchanan, I.D., and Ikonomou, M.G., 2008, Seasonal variability of the reduction in estrogenic activity at a municipal WWTP: Water Research, v. 42, no. 12, p. 3075-3081.

Ford, A.T., Martins, I., and Fernandes, T.F., 2007, Population level effects of intersexuality in the marine environment: Science of the Total Environment, v. 374, no. 1, p. 102-111.

Foreman, W.T., Gray, J.L., ReVello, R.C., Lindley, C.E., Losche, S.A., and Barber, L.B., 2012, Determination of steroid hormones and related compounds in filtered and unfiltered water by solid-phase extraction, derivatization, and gas chromatography with tandem mass spectrometry: U.S. Geological Survey Techniques and Methods, book 5, chap. B9, 131 p.

Foster, W.G., 2001, Endocrine disruption and human reproductive effects: An overview: Water Quality Research Journal of Canada, v. 36, no. 2, p. 253-271.

Furlong, E.T., Gray, G.L., Quanrud, D.M., Teske, S.S., Esposito, K., Marine, J., Ela, W.P., Stinson, B., Kolpin, D.W., and Phillips, P.J., 2010, Fate of estrogenic compounds during municipal sludge stabilization and dewatering: Water Environment Research Foundation, Alexandria, Va., Report 04-HHE-6, 140 p. 
Gibson, R., Smith, M.D., Spary, C.J., Tyler, C.R., and Hill, E.M., 2005, Mixtures of estrogenic contaminants in bile of fish exposed to wastewater treatment works effluents: Environmental Science \& Technology, v. 39, no. 8, p. 2461-2471.

Goodbred, S.L., Gilliom, R.J., Gross, T.S., Denslow, N.D., Bryant, W.L., and Schoeb, T.R., 1997, Reconnaissance of 17 $\beta$-estradiol, 11-ketotestosterone, vitellogenin, and gonad histopathology in common carp of United States streams: Potential for contaminant-induced endocrine disruption: U.S. Geological Survey Open-File Report 96-627, 47 p.

Gordon, D.A., Toth, G.P., Graham, D.W., Lazorchak, J.A., Redd, T.V., Knapp, C.W., deNoyelles, F., Campbell, S., and Lattier, D.L., 2006, Effects of eutrophication on vitellogenin gene expression in male fathead minnows (Pimephales promelas) exposed to 17 alpha- ethynylestradiol in field mesocosms: Environmental Pollution, v. 142, no. 3, p. 559-566.

Green Brody, J., Aschengrau, A., McKelvey, W., Swartz, C.H., Kennedy, T., and Rudel, R.A., 2006, Breast cancer risk and drinking water contaminated by wastewater: a case control study: Enviromental Health, v. 5, no. 28.

Guillette, L.J., 2000, Contaminant-associated endocrine disruption in reptiles, in Sparling, D.W., Linder, G., and Bishop, C.A., eds., Ecotoxicology of of amphibians and reptiles: Pensacola, Fla., Setac Press, p. 595-615.

Harris, C.A., Santos, E.M., Janbakhsh, A., Pottinger, T.G., Tyler, C.R., and Sumpter, J.P., 2001, Nonylphenol affects gonadotropin levels in the pituitary gland and plasma of female rainbow trout: Environmental Science \& Technology, v. 35, no. 14, p. 2909-2916.

Hemming, J.M., Allen, H.J., Thuesen, K.A., Turner, P.K., Waller, W.T., Lazorchak, J.M., Lattier, D., Chow, M., Denslow, N., and Venables, B., 2004, Temporal and spatial variability in the estrogenicity of a municipal wastewater effluent: Ecotoxicology and Environmental Safety, v. 57, no. 3, p. 303-310.

Iwanowicz, L.R., Blazer, V.S., Guy, C.P., Pinkney, A.E., Mullican, J.E., and Alvarez, D.A., 2009, Reproductive health of bass in the Potomac, USA, drainage: Part 1. Exploring the effects of proximity to wastewater treatment plant discharge: Environmental Toxicology and Chemistry, v. 28 , no. 5 , p. $1072-1083$.

James, W.H., 2001, Sex ratios at birth as monitors of endocrine disruption: Environmental Health Perspectives, v. 109 , no. 6 , p. A250-A251.
Jobling, Susan, Burn, R.W., Thorpe, K., Williams, R., and Tyler, C.R., 2009, Statistical modeling suggests that antiandrogens in effluents from wastewater treatment works contribute to widespread sexual disruption in fish living in english rivers: Environmental Health Perspectives, v. 117, no. 5 , p. $797-802$.

Jobling, Susan, Coey, S., Whitmore, J.G., Kime, D.E., Van Look, K.J.W., McAllister, B.G., Beresford, N., Henshaw, A.C., Brighty, G., Tyler, C.R., and Sumpter, J.P., 2002, Wild intersex roach (Rutilus rutilus) have reduced fertility: Biology of Reproduction, v. 67, no. 2, p. 515-524.

Jobling, Susan, and Tyler, C.R., 2003, Endocrine disruption in wild freshwater fish: Pure and Applied Chemistry, v. 75, no. 11-12, p. 2219-2234.

Johnson, A.C., and Sumpter, J.P., 2001, Removal of endocrinedisrupting chemicals in activated sludge treatment works: Environmental Science \& Technology, v. 35, no. 4, p. 4697-4703.

Joss, A., Andersen, H., Ternes, T., Richle, P.R., and Siegrist, H., 2004, Removal of estrogens in municipal wastewater treatment under aerobic and anaerobic conditions: Consequences for plant optimization: Environmental Science \& Technology, v. 38, no. 11, p. 3047-3055.

Kasprzyk-Hordern, B., Dinsdale, R.M., and Guwy, A.J., 2008, The occurrence of pharmaceuticals, personal care products, endocrine disruptors and illicit drugs in surface water in South Wales, UK: Water Research, v. 42, no. 13, p. 3498-3518.

Kidd, K.A., Blanchfield, P.J., Mills, K.H., Palace, V.P., Evans, R.E., Lazorchak, J.M., and Flick, R.W., 2007, Collapse of a fish population after exposure to a synthetic estrogen: Proceedings of the National Academy of Sciences, v. 104, no. 21, p. 8897-8901.

Kim, S.D., Cho, J., Kim, I.S., Vanderford, B.J., and Snyder, S.A., 2007, Occurrence and removal of pharmaceuticals and endocrine disruptors in South Korean surface, drinking, and waste waters: Water Research, v. 41, no. 5, p. 1013-1021.

Kolpin, D.W., Furlong, E.T., Meyer, M.T., Thurman, E.M., Zaugg, S.D., Barber, L.B., and Buxton, H.T., 2002, Pharmaceuticals, hormones, and other organic wastewater contaminants in U.S. streams, 1999-2000: A national reconnaissance: Environmental Science \& Technology, v. 36, no. 6, p. 1202-1211. 
Kolpin, D.W., Skopec, M., Meyer, M.T., Furlong, E.T., and Zaugg, S.D., 2004, Urban contribution of pharmaceuticals and other organic wastewater contaminants to streams during differing flow conditions: Science of the Total Environment, v. 328, no. 1-3, p. 119-130.

Korner, W., Hanf, V., Schuller, W., Kempter, C., Metzger, J., and Hagenmaier, H., 1999, Development of a sensitive E-screen assay for quantitative analysis of estrogenic activity in municipal sewage plant effluents: The Science of the Total Environment, v. 225, no. 1-2, p. 33-48.

Leusch, F.D.L., De Jager, C., Levi, Y., Lim, R., Puijker, L., Sacher, F., Tremblay, L.A., Wilson, V.S., and Chapman, H.F., 2010, Comparison of five in vitro bioassays to measure estrogenic activity in environmental waters: Environmental Science \& Technology, v. 44, no. 10, p. 3853-3860.

McCarthy, I.D., Fuiman, L.A., and Alvarez, M.C., 2003, Aroclor 1254 affects growth and survival skills of Atlantic croaker Micropogonias undulatus larvae: Marine Ecology Progress Series, v. 252, p. 295-301.

Mount, D.I., 1982, Principles and Concepts of Effluent Testing, in Bergman, H.L., Kimerle, R.A., and Maki, A.W., eds., Environmental hazard assessment of effluents: Oxford, England, Pergamon Press, p. 61-65.

Nagy, P., Fekete, J., and Sharma, V.K., 2005, Octylphenol and nonylphenol in surface water of Rackevei-Soroksari Danube branch, Hungary: Journal of Environmental Science and Health, v. 40, no. 9, p. 1679-1688.

Nichols, K.M., Snyder, E.M., Snyder, S.A., Pierens, S.L., Miles-Richardson, S.R., and Giesy, J.P., 2001, Effects of nonylphenol ethoxylate exposure on reproductive output and bioindicators of environmental estrogen exposure in fathead minnows, Pimephales promelas: Environmental Toxicology and Chemistry, v. 20, no. 3, p. 510-522.

Oh, S.M., Park, K., and Chung, K.H., 2006, Combination of in vitro bioassays encompassing different mechanisms to determine the endocrine-disrupting effects of river water: Science of the Total Environment, v. 354, no. 2-3, p. 252-264.

Park, K.J., Muller, C.T., Markman, S., Swinscow-Hall, O., Pascoe, D., and Buchanan, K.L., 2009, Detection of endocrine disrupting chemicals in aerial invertebrates at sewage treatment works: Chemosphere, v. 77, no. 11, p. 1459-1464.

Peltier, W., 1978, Methods for measuring the acute toxicity of effluents to aquatic organisms: U.S. Environmental Protection Agency EPA-600/4-78-012, 52 p.
Petrovic, M., Sole, M., deAlda, M.J.L., and Barcelo, D., 2002, Endocrine disruptors in sewage treatment plants, receiving river waters, and sediments: Integration of chemical analysis and biological effects on feral carp: Environmental Toxicology and Chemistry, v. 21, no. 10, p. 2146-2156.

Phillips, P.J., Smith, S.G., Kolpin, D.W., Zaugg, S.D., Buxton, H.T., Furlong, E.T., Esposito, K., and Stinson, B., 2010, Pharmaceutical formulation facilities as sources of opioids and other pharmaceuticals to wastewater treatment plant effluents: Environmental Science \& Technology, v. 44, no. 13, p. 4910-4916.

Phillips, P.J., Stinson, B., Zaugg, S.D., Furlong, E.T., Kolpin, D.W., Esposito, K.M., Bodniewicz, B., Pape, R., and Anderson, J., 2005, A multi-disciplinary approach to the removal of emerging contaminants in municipal wastewater treatment plants in New York State, 2003-2004, in Water Environment Federation 78th Annual Technical Exhibition and Conference: Washington, D.C., p. 5095-5124.

Rajapakse, N., Silva, E., and Kortenkamp, A., 2002, Combining xenoestrogens at levels below individual no-observed-effect concentrations dramatically enhances steroid hormone action: Environmental Health Perspectives, v. 110 , no. 9, p. 917-921.

Rajapakse, N., Silva, E., Scholze, M., and Kortenkamp, A., 2004, Deviation from additivity with estrogenic mixtures containing 4-nonylphenol and 4-tert-octylphenol detected in the E-SCREEN assay: Environmental Science \& Technology, v. 38, no. 23, p. 6343-6352.

Rempel, M.A., Reyes, J., Steinert, S., Hwang, W., Armstrong, J., Sakamoto, K., Kelley, K., and Schlenk, D., 2006, Evaluation of relationships between reproductive metrics, gender and vitellogenin expression in demersal flatfish collected near the municipal wastewater outfall of Orange County, California, USA: Aquatic Toxicology, v. 77, no. 3, p. 241-249.

Routledge, E.J., Sheahan, D., Desbrow, C., Brighty, G.C., Waldock, M., and Sumpter, J.P., 1998, Identification of estrogenic chemicals in STW effluent. 2. In vivo responses in trout and roach: Environmental Science \& Technology, v. 32 , no. 11 , p. $1559-1565$.

Schultz, M.M., Furlong, E.T., Kolpin, D.W., Werner, S.L., Schoenfuss, H.L., Barber, L.B., Blazer, V.S., Norris, D.O., and Vajda, A.M., 2010, Antidepressant pharmaceuticals in two U.S. effluent-impacted streams: Occurrence and fate in water and sediment, and selective uptake in fish neural tissue: Environmental Science \& Technology, v. 44, no. 6, p. 1918-1925. 
Schultz, M.M., Painter, M.M., Bartell, S.E., Logue, A., Furlong, E.T., Werner, S.L., and Schoenfuss, H.L., 2011, Selective uptake and biological consequences of environmentally relevant antidepressant pharmaceutical exposures on male fathead minnows: Aquatic Toxicology, v. 104 , no. $1-2$, p. $38-47$.

Shappell, N.W., 2006, Estrogenic activity in the environment: Municipal wastewater effluent, river, ponds, and wetlands: Journal of Enviromental Quality, v. 35, no. 1, p. 122-132.

Shelton, L.R., and Capel, P.D., 1994, Guidelines for collecting and processing samples of stream bed sediment for analysis of trace elements and organic contaminants for the National Water-Quality Assessment program: U.S. Geological Survey Open-File Report 94-458, 20 p.

Silva, E., Rajapakse, N., and Kortenkamp, A., 2002, Something from "Nothing" - Eight weak estrogenic chemicals combined at concentrations below NOECs produce significant mixture effects: Environmental Science \& Technology, v. 36 , no. 8 , p. 1751-1756.

Soto, A.M., Sonnenschein, C., Chung, K.L., Fernandez, M.F., Olea, N., and Serrano, F.O., 1995, The E-SCREEN assay as a tool to identify estrogens: an update on estrogenic environmental pollutants: Enviromental Health Perspectives, v. 103, no. 7, p. 113-122.

Thorpe, K.L., Cummings, R.I., Hutchinson, T.H., Scholze, M., Brighty, G., Sumpter, J.P., and Tyler, C.R., 2003, Relative potencies and combination effects of steroidal estrogens in fish: Environmental Science \& Technology, v. 37, no. 6, p. 1142-1149.

Tyler, C.R., vanderEerden, B., Jobling, Susan, Panter, G., and Sumpter, J.P., 1996, Measurement of vitellogenin, a biomarker for exposure to oestrogenic chemicals, in a wide variety of cyprinid fish: Journal of Comparative Physiology, v. 166 , no. 7 , p. $418-426$.

U.S. Environmental Protection Agency (USEPA), 1983a, Methods for chemical analysis of water and wastes: U.S. Government Printing Office, 491 p.

U.S. Environmental Protection Agency, 1983b, Water Quality Standards Handbook - Guidelines for deriving site-specific water quality criteria: Office of Water Regulations and Standards, Washington, D.C., 186 p.
U.S.Geological Survey, 2006, National field manual for the collection of water-quality data: U.S. Geological Survey Techniques of Water-Resources Investigations, book 9 , chap. A1-A9.

Vajda, A.M., Barber, L.B., Gray, J.L., Lopez, E.M., Woodling, J.D., and Norris, D.O., 2008, Reproductive disruption in fish downstream from an estrogenic wastewater effluent: Enviromental Science \& Technology, v. 42, no. 9, p. 3407-3414.

Wang, L.Y., Zhang, X.H., and Tam, N.F.Y., 2010a, Analysis and occurrence of typical endocrine-disrupting chemicals in three sewage treatment plants: Water Science and Technology, v. 62, no. 11, p. 2501-2509.

Wang, R.L., Bencic, D., Villeneuve, D.L., Ankley, G.T., Lazorchak, J., and Edwards, S., 2010b, A transcriptomicsbased biological framework for studying mechanisms of endocrine disruption in small fish species: Aquatic Toxicology, v. 98 , no. 3, p. 230-244.

Wise, A., O’Brien, K., and Woodruff, T., 2011, Are oral contraceptives a significant contributor to the estrogenicity of drinking water?: Environmental Science \& Technology, v. 45 , no. 1 , p. $51-60$.

Zaugg, S.D., Smith, S.G., Schroeder, M.P., Barber, L.B., and Burkhardt, M.R., 2002, Methods of analysis by the U.S. Geological Survey National Water Quality LaboratoryDetermination of wastewater compounds by polystyrenedivinylbenzene solid-phase extraction and capillary-column gas chromatography/mass spectrometry: U.S. Geological Survey Water-Resources Investigations Report 01-4186, $37 \mathrm{p}$.

Zhang, Y.P., and Zhou, J.L., 2005, Removal of estrone and 17 beta-estradiol from water by adsorption: Water Research, v. 39 , no. 16 , p. $3991-4003$.

Zhang, Z.H., Feng, Y.J., Gao, P., Wang, C., and Ren, N.Q., 2011, Occurrence and removal efficiencies of eight EDCs and estrogenicity in a STP: Journal of Environmental Monitoring, v. 13, no. 5, p. 1366-1373. 
Appendix 1. Concentrations of wastewater compounds in unfiltered water from sites sampled as part of the estrogenicity study, 2008-9. (appendix 1)

\section{Appendix 2. Concentrations of hormones in unfiltered water from sites} sampled as part of the estrogenicity study, 2008-9. (appendix 2) 
Prepared by the Pembroke Publishing Service Center.

For more information concerning this report, contact:

\section{Director}

U.S. Geological Survey

New York Water Science Center

425 Jordan Road

Troy, NY 12180-8349

dc_ny@usgs.gov

or visit our Web site at:

http://ny.water.usgs.gov 


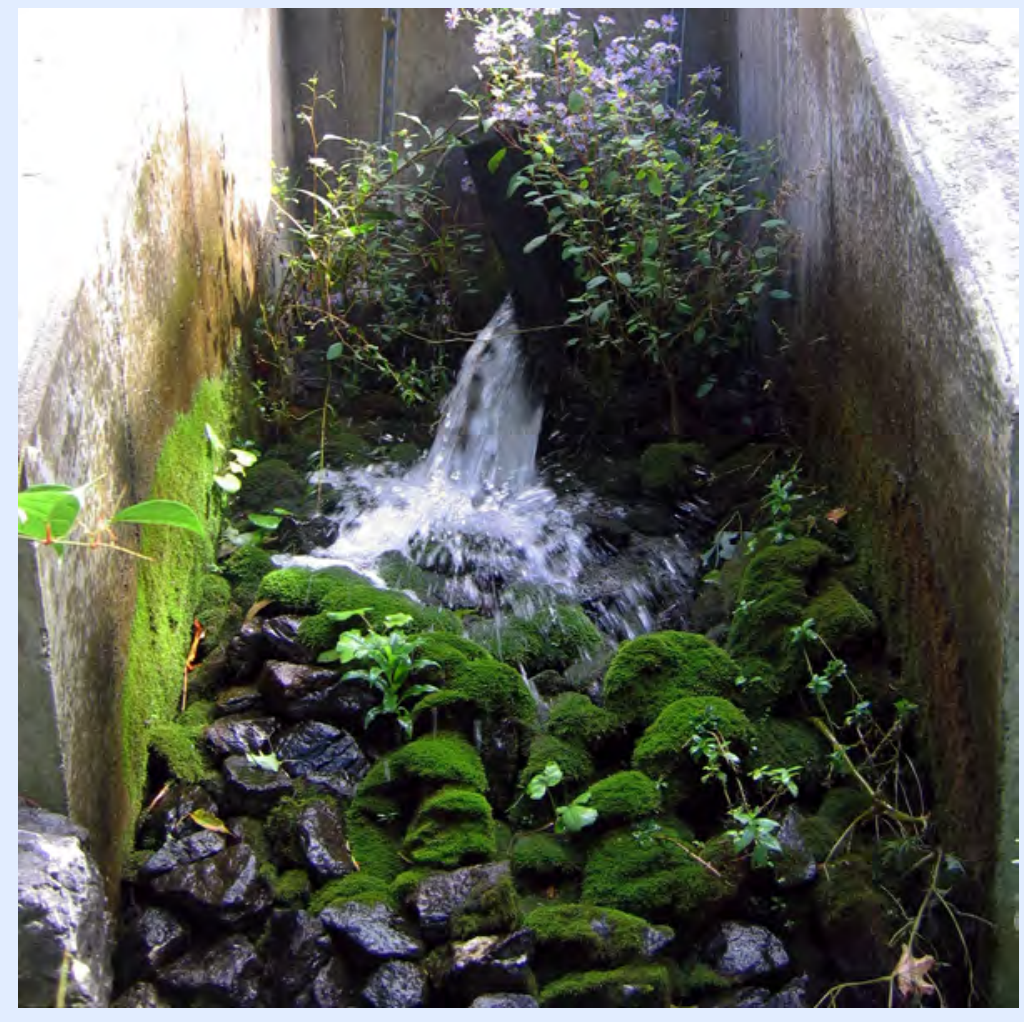

